This item was submitted to Loughborough's Research Repository by the author.

Items in Figshare are protected by copyright, with all rights reserved, unless otherwise indicated.

\title{
State control and corporate governance in transition economies: 25 years on from 1989
}

PLEASE CITE THE PUBLISHED VERSION

http://dx.doi.org/10.1111/corg.12145

\section{PUBLISHER}

(C) John Wiley \& Sons

\section{VERSION}

AM (Accepted Manuscript)

\section{PUBLISHER STATEMENT}

This work is made available according to the conditions of the Creative Commons Attribution-NonCommercialNoDerivatives 4.0 International (CC BY-NC-ND 4.0) licence. Full details of this licence are available at: https://creativecommons.org/licenses/by-nc-nd/4.0/

\section{LICENCE}

CC BY-NC-ND 4.0

\section{REPOSITORY RECORD}

Grosman, Anna, Ilya Okhmatovskiy, and Mike Wright. 2015. "State Control and Corporate Governance in Transition Economies: 25 Years on from 1989". Loughborough University. https://hdl.handle.net/2134/22926. 
State Control and Corporate Governance in Transition Economies: 25 Years on from

1989

\author{
Anna Grosman ${ }^{1}$, Ilya Okhmatovskiy, and Mike Wright
}

\begin{abstract}
Manuscript type: Review

Research Question/ Issue: Which forms of state control over corporations have emerged in countries that made a transition from centrally-planned to marked-based economies and what are their implications for corporate governance? We assess the literature on variation and evolution of state control in transition economies focusing on corporate governance of statecontrolled firms. We highlight emerging trends and identify future research avenues.
\end{abstract}

Research Findings/ Insights: Based on our analysis of more than a hundred articles in leading management, finance and economics journals since 1989, we demonstrate how research on state control evolved from a polarized approach of public - private equity ownership comparison to studying a variety of constellations of state capitalism.

Theoretical/ Academic Implications: We identify theoretical perspectives that help us better understand benefits and costs associated with various forms of state control over firms. We encourage future studies to examine how context-specific factors determine the effect of state control on corporate governance.

Practitioner/ Policy Implications: Investors and policy-makers should consider under which conditions investing in state-affiliated firms generates superior returns.

Keywords: Corporate Governance; Transition Economies; State Capitalism; SOEs; Review; China; Russia

\footnotetext{
${ }^{1}$ Address for correspondence: Anna Grosman, Aston Business School, Aston University, Aston Triangle, Birmingham B4 7ET, UK. Tel: +44 121204 3815; E-mail: a.grosman@aston.ac.uk
} 


\section{INTRODUCTION}

Over a quarter of a century since the fall of the Berlin Wall, former communist regimes have transitioned to democratic or semi-democratic regimes, although the process of becoming market economies has advanced at different rates and directions across countries. Transition economies represent a large sub-category of emerging economies (Hoskisson, Eden, Lau, \& Wright, 2000; Hoskisson, Wright, Filatotchev, \& Peng, 2013). Given the 25 years since 1989, it is timely to review how means of state control have changed in these transition economies.

While developed economies have seen a gradual demise of state-owned enterprises (SOEs) and there has been extensive privatization in emerging economies, state capitalism is a popular choice among transition economies (Wooldridge, 2012). Accordingly, we address the following research question: "Which forms of state control over corporations have emerged in countries that made a transition from centrally-planned to marked-based economies and what are their implications for corporate governance?" To address this question, we suggest a taxonomy of state control used to structure our literature review.

We consider the transformation of state control in transition economies focusing on the emergence of contemporary forms of state capitalism following privatizations of the 1990s. Earlier reviews focused on privatization comparing performance of state-owned and privatized companies (Estrin \& Wright, 1999; Megginson \& Netter, 2001; Djankov \& Murrell, 2002), but interactions between state and private sector have evolved and new forms of state control have emerged. Our motivation is driven by a lack of comprehensive reviews encompassing the evolution and variety of state control over firms and their governance implications. We fill this gap by bringing together studies scattered across several disciplines and identifying relevant theoretical perspectives that suggest positive and negative effects of state control, as summarized in Table 1. 
Insert Table 1 about here

We searched for studies that examine state control and corporate governance of firms in transition economies. The first category of studies considered various mechanisms of state control: partial ownership, board of directors, veto rights, managerial incentives, loans, and regulation. The second category analyzed relationships between state control and corporate governance. We did not cover studies about performance implications of state control, these implications have been discussed by Musacchio Lazzarini, and Aguilera (2015).

We analyzed more than a hundred articles published since 1989 focusing on peerreviewed studies (Seglen, 1994; Pugliese, Bezemer, Zattoni, Huse et al., 2009), but also included in our review books and book chapters containing significant empirical material. We did not review studies about traditional SOEs with state as the sole shareholder - such enterprises were covered by earlier reviews on privatization (Megginson \& Netter, 2001). Instead we focused on partial state ownership and indirect state ownerships via intermediaries. We generally refer to such firms as SOEs. Key studies representing different theoretical perspectives and different transition economies are shown in Table 2.

Insert Table 2 about here

We adopt a broad definition of 'transition economies' to include former socialist countries of Central and Eastern Europe, former republics of the Soviet Union, and Asian countries emerging from a socialist-type command economy towards a market-based economy (China, Laos, Cambodia, Mongolia, and Vietnam). Many of these economies have 
completed transition to a market economy. The countries that joined the EU - Czech Republic, Estonia, Hungary, Latvia, Lithuania, Poland, Slovakia, and Slovenia in 2004, followed by Romania and Bulgaria in 2007, and Croatia in 2013, are no longer in transition.

We mainly focus on the two largest transition economies, China and Russia (drawing some comparisons with smaller transition economies), because of the economic and political importance of SOEs in these countries and because studies overwhelmingly relate to these two countries (Bruton, Peng, Ahlstrom, Stan et al., 2015; Musacchio et al., 2015). Comparing China and Russia helps identify context-specific factors affecting corporate governance of state-controlled companies. Timelines of the main events affecting state control and corporate governance in China and Russia are shown in Tables 3 and 4, respectively.

Insert Tables 3 and 4 about here

The paper is structured as follows. First, we outline a range of forms of state control going beyond dominant ownership positions, including government loans, appointments of state officials to board or top management positions, party committees, special veto rights, regulation, and business-government networks, and consider how these have evolved over time in China, Russia and other transition economies. Second, we review the literature on governance structures and processes with particular attention to board composition and independence, transparency and disclosure, and executive compensation in state-controlled firms operating in transition economies. Finally, we elaborate an agenda for future research on corporate governance implications of state control taking into account the variety of transition economies. 


\section{MEANS OF STATE CONTROL: VARIATION AND EVOLUTION OVER TIME}

Over the last 25 years, public perception and academic reasoning about the role of state in transition economies have fluctuated sharply. During the early 90s, the pro-market and antistate climate reigned following the collapse of communist regimes. Research on SOEs in transition economies during our focal period started with privatization studies (Aharoni, 1986; Ramamurti \& Vernon, 1991; Djankov \& Murrell, 2002; Estrin \& Wright, 1999). These studies viewed SOEs as a temporary organizational form because privatization of SOEs was widely anticipated (Spicer, McDermott, \& Kogut, 2000; Dewenter \& Malatesta, 2001). In the second half of the 1990s, initial euphoria over privatization in planned economies began to wane as the hard work of enterprise restructuring continued. Since mid-2000s, the pace of privatization and deregulation has slowed. During this period, private investors were often offered minority stakes, with the state keeping a controlling stake. A new form of state capitalism developed, influenced by increasing globalization and market-orientation. To address this transformation, a more recent literature emerged devoted to partial state ownership (Inoue, Lazzarini, \& Musacchio, 2013) and other forms of state control. As the overwhelming majority of studies about state control have been conducted in China (Bruton et al., 2015), we begin by reviewing these studies and then consider studies about state control in Russia and other transition economies.

\section{Variation and Evolution of State Control in China}

SOEs with Partial State Ownership. China took a reform approach of 'gradualism' (Wang, Guthrie, \& Xiao, 2011), preserving state control while implementing new institutional forms. In the 1980 s, China decentralized state control to provincial, municipal, township and village level governments, at the same time allowing private sector emergence. During the 1990s reforms, China's state vowed to "hold onto the big and let go of the small" 
(zhua da fang xiao) (Fernandez \& Fernandez-Stembridge, 2007). As a result, China developed a complex system of state ownership with elaborated control mechanisms (Delios, $\mathrm{Wu}, \&$ Zhou, 2006). The Chinese state retained stakes (often non-controlling) in privatized medium-sized SOEs and imposed restrictions on non-state share transfers. Large SOEs remained under government control, but some were partly privatized later (Cao, Qian, \& Weingast, 1999). Gradualism had two benefits. First, it allowed the state to retain its stabilizing role. Second, the central government pushed ownership control down to localities, creating an incentive structure similar to those experienced by managers of large industrial firms.

Continuing central government commitment to support employment in SOEs implied state-owned banks usually bailed out loss-making SOEs, creating 'soft budget' constraints (Zhu, 2012). This strategy resulted in "reform without losers" (Lau, Qian, \& Roland, 2000) and helped minimize social instability and reduce resistance to reform. In contrast, central government had no commitment to support employment in township and village enterprises (TVEs). Thus, TVEs faced a much tighter budget constraint and stronger market discipline than SOEs controlled by central government. However, from the mid-1990s, central government progressively reduced commitment to support employment in SOEs, and many small and medium-sized SOEs went bankrupt or were privatized. More diversified ownership was introduced with some larger SOEs being converted into shareholding companies, with majority of shares controlled by the state.

This restructuring led to productivity growth and a decline in SOEs' share of labor (Zhu, 2012). The Chinese government aimed at selectively fortifying SOE presence in specific industries (Nolan, 2001) and in developing SOEs into globally competitive firms (Ralston, Terpstra-Tong, Terpstra, Wang et al., 2006). In 2000, China launched its 'Go Global' policy, establishing some SOEs as 'national champions' and leading to SOEs 
globalization (Thun, 2004; Liang, Ren, \& Sun, 2015). SOEs' culture became close to those of privately and foreign-owned businesses (Granrose, Huang, \& Reigadas, 2000). However, the Chinese government did not desire to completely eradicate former hierarchical structures.

A key ingredient of reforms was 'corporatization' of SOEs which meant that they fell under the jurisdiction of the 1994 Company Law, aimed at promoting corporate property rights and corporate governance structures. Corporatized SOEs were subsequently listed on the Shanghai and Shenzhen stock exchanges (Firth, Fung, \& Rui, 2006) to access private and foreign capital. Moreover, China started the split-share structural reform in 2006 as a part of its program to transfer state shares in SOEs to private investors (Haveman \& Wang, 2013) and to transform the corporate governance model from administrative to more marketoriented (Ralston et al., 2006). Typically, when a Chinese SOE was listed, only a small proportion of equity was sold to private investors (Conyon \& He, 2011) with the state and parent SOEs keeping voting control. Sheng and Zhao (2013) show that recently the "state advance and private retreat" phenomenon (guo jin min tui) has been gaining ground China's government has strengthened control over SOEs with private capital being forced to withdraw from major industries, especially those related to national security.

Indirect State Ownership Control. The state maintained indirect control after corporatization as state shares were 'placed' in the State-Owned Asset Management Companies (SOAMCs); and under the control of the State-Owned Assets Supervision and Administration Commission (SASAC), charged with transforming and controlling the largest and most powerful of SOEs. SASAC was also responsible for appointing and removing top executives at SOEs, setting executive compensation, improving corporate governance and setting SOEs' operating budgets and ensuring workplace safety at SOEs (Jiang \& Kim, 2015). From 1998 to 2003 shares directly owned by the state declined from 67.3 percent to 23.5 percent, while state institutional shares (owned by SOAMCs/ SASAC) rose from 1.8 
percent to 44.4 percent (Wang et al., 2011). Researchers still have to explore how much autonomy SOAMCs enjoy.

Means of Control beyond Ownership. In transition economies the state often supported and influenced distressed firms through soft budgets (Djankov \& Murrell, 2002). In China, the state responded to the 2008 global financial crisis with a monetary stimulation entailing internal transfers between arms of the government, banking and corporate sectors (Deng, Morck, Wu, \& Yeung, 2015). However, monitoring of controlling shareholders by state banks was often inefficient with banks lending to firms even when firms' controlling shareholders were tunneling resources from these firms (Qian \& Yeung, 2015).

Appointments of former or current state officials to board or top management positions in China were common in the 1990s. Such political ties are used by managers to access officials and resources (Walder, 1995). However, bureaucrats seek rents from firms and there is evidence of lower performance and growth in politically connected firms (Fan, Wong, \& Zhang, 2007). Moreover, the effect on performance is contingent upon tie type. Political ties to local governments can improve firm survival ('buffering') and performance ('enabling'), unlike ties to the central government (Zheng, Singh, \& Mitchell, 2014). Such effects are also contingent upon firm's prior performance.

State involvement in listed SOEs is enabled by the often overlapping dual governance structure: the corporate board and the Party Committee (headed by its Party Secretary). Even where the two structures do not overlap, real power still flows through the Party Committee, which often simply follows Communist Party orders (Morck, Yeung, \& Zhao, 2008). The latter also appoints CEOs of the largest SOEs.

Networks of Private and State Actors. China's economy is characterized as 'networked capitalism', involving complex partnerships between firms and state (Boisot \& 
Child, 1996). Decentralization processes in the 1990s led to central ministries retaining control over larger strategic SOEs and leaving smaller SOEs under interdependent control of local governments and private entrepreneurs. The connections (or quanxi) with the bureaucracy may lead to the creation of special networks for channeling resources and forging mutual partner alliances between private businesses and the state (Wank, 1995). Start-ups may strategically appoint outside directors to seek help in dealing with government (Chen, 2015). State connections are associated with less severe financial constraints (Cull, Li, Sun, \& Xu, 2015). Firms are actively looking for various means of building their businessstate networks and rendering favors to government officials, for example, by engaging in corporate social responsibility that promotes social welfare (Lin, Tan, Zhao, \& Karim, 2015).

Political connections helped China's tycoons amass phenomenal wealth in real estate, finance, high tech and mining. In 2015, China had over 200 billionaires ranking second after US (Forbes, 2015). However, contrary to Russian oligarchs, China's tycoons were mostly self-made, did not obtain their assets from privatizations, and were not former bureaucrats.

\section{Variation and Evolution of State Control in Russia}

SOEs with Partial State Ownership. Russian mass privatization in the early / mid1990s was radical compared with gradualism in China. Such aggressive privatization has been criticized as premature given weakness of the institutional infrastructure (Black, Kraakman, \& Tarassova, 2000) and justified as the only feasible option given the political environment at the time (Boycko, Shleifer, \& Vishny, 1995). Privatization methods in Russia favored employees and, especially, managers leading to managerial entrenchment (Filatotchev, Wright, \& Bleaney, 1999). Powerful positions of managers and weakness of corporate governance mechanisms often left the state as passive minority shareholder during the early reform period (Pistor \& Turkewitz, 1996; Estrin \& Wright, 1999). 
Since 2000 the state has adopted a different approach by transforming selected SOEs into profitable, rapidly expanding industry leaders and by offering minority stakes in these enterprises to private investors - such investments could bring good return but minimal control rights. This approach allowed the state to enhance control over large strategically important enterprises while divesting holdings in relatively insignificant enterprises (Chernykh, 2011). This trend stimulated interest in the implications of dominant state ownership for minority investors (Yakovlev, 2009).

Indirect State Ownership Control. State ownership of Russian companies would be dramatically underestimated if we considered just direct ownership (Chernykh, 2008). Indirect state ownership reflects the prominence of state holding companies (such as UES or Svyazinvest) as well as aggressive acquisition strategies of some SOEs (such as Gazprom, Rosneft, or VTB). Adding indirect state ownership increases the proportion of publicly listed companies controlled by the state from 14.1 percent to 37 percent with a conservative 50 percent control threshold and to 57.5 percent with a 25 percent control threshold (Chernykh, 2008). Since 2004, acquisition of substantial stakes in formerly privatized companies by large SOEs became a systematic practice gradually increasing the state-owned share of market capitalization from 20 percent in 2003 to 50 percent by 2012 (Enikolopov \& Stepanov, 2013). These aggressive acquisition strategies of several large SOEs resulted in de facto renationalization of many enterprises that were privatized in the 1990s (Chernykh, 2011). This practice substantially boosted state control over the Russian economy even though de jure there was no renationalization during this period.

Means of Control beyond Ownership. Appointment of acting government officials as board members and appointment of former government officials as top executives of companies with partial or indirect state ownership represent one means of enhancing state control beyond ownership. The presence of government officials on Russian boards has been 
examined in several studies (e.g., Wright, Buck, \& Filatotchev, 1998; Frye \& Iwasaki, 2011).The presence of state representatives appears persistent even when state ownership declines following privatization (Radygin, Entov, Gontmakher, Mezheraups et al., 2004). Studies of Russian firms with government board representatives provide evidence of collusive relationships: firms with state directors are more likely to receive state benefits and to provide services that benefit the state (Frye \& Iwasaki, 2011).

In the 1990s, the state often acted as a passive shareholder and rarely used the board as a mechanism for exercising control over management. However, in the early 2000 s, the state became a more active shareholder and appointed senior government officials to the boards of SOEs. In 2011 President Medvedev initiated the removal of top government officials from the boards of directors of SOEs, but this initiative has recently been reversed.

While we have systematic evidence about appointment of government officials to boards and their involvement in corporate governance, there are no systematic studies about appointment of former government officials as executives of SOEs and the implications of such appointments for strategic choices. It would be useful to examine systematically the professional background of top management teams to identify how often executives had government careers before assuming positions in SOEs. Another aspect of the 'revolving door' between business and government is represented by government appointments of prominent business leaders. This practice has not been studied systematically, but appointments of business leaders to key government positions were common in the 1990s under President Yeltsin's administration.

A second means of enhancing control beyond ownership occurs through veto rights provided by a 'golden share' (Frye \& Iwasaki, 2011). Golden shares were frequently used in the 1990 s but more recently the Russian government has abandoned its special voting rights 
in some SOEs. In other firms, the government increased its stake substantially thus making obsolete special voting rights provided by the golden share.

A third mechanism that allows the state to exercise influence beyond ownership is based on companies' dependence on the state as a provider of resources. Thus, the statecontrolled Vneshekonombank was providing refinancing to many large "strategically important" companies in a critical condition after the 2008 financial crisis (Radygin, 2008). The recipients were expected to reciprocate by avoiding massive lay-offs, salary cuts, or significant increases in output prices (Simachev \& Kuzyk, 2012). These de facto bailouts were not associated with a substantial increase in the number of SOEs (Enikolopov \& Stepanov, 2013), but provided state agencies with significant leverage over private companies to demand that they avoid taking actions with high social costs.

Fourth, regulation represents another state control channel. Limited effectiveness of the Russian government as a regulator is reflected not only in problems with enforcement of rules (Spicer \& Okhmatovskiy, 2015), but also in the practice of modifying general rules to create favorable conditions for specific companies loyal to federal or regional governments. Such favoritism creates strong incentives for private companies to coordinate actions with government agencies to the extent that these private companies initiate large business transactions only after informal approval from government agencies (Radygin, 2008). SOEs often rely on regulatory support from the government and this practice benefits private shareholders investing in SOEs. However, by playing simultaneously the roles of owner and regulator, the state creates conflicts of interest that perpetuate the perception of market regulations in Russia as biased and inconsistent.

Networks of Private and State Actors. Of particular relevance to the study of state control is the relationship between the Russian top politicians and industrial tycoons 
('oligarchs') (Guriev \& Rachinsky, 2005). When Mr. Putin came to power, he offered to accept oligarchs' ownership rights obtained through the opaque privatization process if they did not get involved in politics (Puffer \& McCarthy, 2007). Some oligarchs adapted by befriending the state and generating synergies from operating together (Melkumov, 2009). The state 'authorized' these tycoons to get rich and they were inclined to cooperate with the state (Adachi, 2013). Oligarch-owned firms were often structured as pyramids or through cross-shareholdings. In these structures, the oligarch achieved control of constituent firms via a chain of ownership relations, often including the state as another controlling shareholder. These oligarchic-state network structures filled the institutional vacuum left by the collapsed communist economy, ensuring access to the requisite resources for investments and improving assets' productivity (Grosman \& Leiponen, 2013). However, the power of oligarchs over the companies within their control also created opportunities for tremendous private gains, often at the expense of minority shareholders and potentially to the detriment of the overall economy.

For many oligarchs, close connections to the state are rooted in their affiliation with nomenklatura circles through early careers or personal connections. Others started as 'outsiders' but over the years developed a special relationship with the state (Braguinsky, 2009). The oligarchs' relationships with the state also took more formal formats as exemplified by official meetings of Mr. Yeltsin and Mr. Putin with the group of the most prominent oligarchs and by establishment of a powerful lobbying association, Russian Union of Industrialists and Entrepreneurs, representing mostly interests of large business owners (Hanson \& Teague, 2005).

The emergence of networks where private and state actors were interconnected through joint ownership of partially privatized property created conditions for mutual influence. The balance of such influence shifted over time. In the 1990s, relationships 
between business and the state were described as "state capture" (Hellman, Jones, \& Kaufmann, 2003). After 2000, when political leaders gained strength and obtained broad public support, relationships shifted to "business capture" as political leaders leveraged their powerful position by dictating the conditions of continuing partnership with private actors (Yakovlev, 2006).

\section{Variation and Evolution of State Control in Other Transition Economies}

SOEs with Partial State Ownership. Research on SOEs in transition economies of Central and Eastern Europe (CEE) and in former Soviet republics (CIS countries) has primarily concerned challenges associated with privatization and restructuring (Claessens \& Djankov, 1999; Uhlenbruck, Meyer, \& Hitt, 2003), governance structures (Filatotchev, Buck, \& Zhukov, 2000), and more recently, divergent paths in transition (Lane \& Myant, 2007), and European integration (Hashi, Welfens, \& Wziatek-Kubiak, 2007).

From the historical perspective, it is most useful to compare state control transformation and evolution in Russia and in other former Soviet republics. Amongst countries that have transitioned most towards the democratic model with the state reducing its control over key assets are the Baltic States (stabilized by the EU anchor), Georgia (aided by Western intellectual and financial support), and Kyrgyz Republic. Countries retaining considerable state power, where state and business elites have close ties, are Belarus, Tajikistan, Turkmenistan, Uzbekistan and Ukraine.

Indirect State Ownership Control. Similar to Russia, indirect state ownership is quite common in CEE and CIS countries. The state often created multiple institutions through which to exercise control, such as investment funds or pension funds (Pahor, Prasnikar, \& Ferligoj, 2004). The state also maintained control over some financial and industrial groups, which in turn controlled individual firms (Kočenda \& Hanousek, 2012). 
Means of State Control beyond Ownership. Financial support through government loans was common in CEE and CIS economies, similar to Russia and China (Mickiewicz, 2010). However, in these economies, ruling political parties did not exercise direct control over firms through governance structures similar to China's Party Committees. Similar to Russia and China, the state in other transition economies frequently executed veto rights through golden shares to prevent entry by new shareholders or to block the sale of property (Kočenda \& Hanousek, 2012).

Networks of Private and State Actors. Partial privatization in CEE produced many firms with mixed private and state ownership described as "recombinant property" by Stark (1996). Several studies analyzed privatized firms not as isolated economic units but as nodes in corporate networks created by the relationships of control and interdependence (Pahor et al., 2004). These dense corporate networks connected domestic owners, foreign owners, and the state thus blurring boundaries between private and state ownership. In many firms, the state assumed the role of a passive shareholder by letting private partners take control (Frydman, Gray, Hessel, \& Rapaczynski, 1999). In others, the state was quite active, with the relationships between state and private shareholders ranging from mutually beneficial cooperation to hostile battles for control.

CEE minimized opportunities for rent-seeking activities of the ruling elite by reducing major distortions of government policies and liberalizing prices (Havrylyshyn, 2006). Oligarchs played a more prominent role in CIS countries, where they were connected with the state either through upper-echelon nomenclature or relatives and close associates of the countries' presidents. In other former Soviet republics, the 'revolving door' between the government and business was often even more pronounced than in Russia; for example, only recently an oligarch in food products, Mr. Poroshenko, became President of Ukraine. Further, 
across all CIS countries, there was considerable continuity from the political power leaders of the Soviet period to the oligarchs.

\section{CORPORATE GOVERNANCE STRUCTURES AND PROCESSES}

\section{Board Composition and Independence}

The notion and functions of independent directors vary remarkably across different jurisdictions (Ferrarini \& Filippelli, 2014). In China, all listed companies are required to have at least one third of independent directors on their boards and, if board committees are established, that proportion should be raised to at least half (Clarke, 2006; Zhao, 2011). The role of independent directors in Chinese audit committees is negligible (Liu \& Pissler, 2013). As to nomination and remuneration committees, the corporate governance code recommends a composition based on a majority of independent directors. However, the influence of such committees on decisions about executive compensation is also modest. The positive relationship between board independence and firm operating performance is stronger in state controlled firms relative to other listed firms in China as it reduces tunneling and improves investment efficiency in SOEs (Liu, Miletkov, Wei, \& Yang, 2015). Former government officials comprise a large share of outside board members in Chinese firms (Chen, 2015). Several studies examine the effect of political connections at the board level (Liang et al., 2015; Fan et al., 2007; Zheng et al., 2014; Cull et al., 2015).

The Russian corporate governance code recommends that boards comprise at least one-third of independent directors. It also recommends that audit committees consist entirely of independent directors or are chaired by an independent director and include only nonexecutives. Board composition may affect investments in productive assets. For Russian publicly traded firms, Grosman and Wright (2015) find a positive effect of cash-flows on capital expenditures when SOEs appoint independent board directors to assume the role of 
monitoring. However, these positive effects are substantially reduced when oligarchs appoint independent directors indicating that independent directors are afforded insufficient autonomy to play their monitoring role. The authors find foreign independent directors to be influential, while foreign affiliated directors exercise little influence on tunneling.

The adoption of best corporate governance practices in state-controlled firms remains quite limited. According to a recent study by the Russian Institute of Directors (2014), the proportion of Russian SOEs with committees composed of only independent or nonexecutive directors is still low (51 percent of nomination and remuneration committees and 57 percent of audit committees). While it is common practice in SOEs to establish board committees, only half of them meet regularly. Only 11 percent of SOEs conducted evaluations of board practice in 2013. Great heterogeneity is observed between partially controlled SOEs and wholly owned SOEs in their board processes and practices, representing good standards in 74 percent of the former and only 56 percent of the latter.

\section{Transparency and Disclosure}

An important question concerns whether state control is associated with higher or lower degree of transparency and disclosure. Relative to other facets of corporate governance, voluntary disclosure by Russian SOEs is higher, but still lags behind the level of disclosure in publicly traded firms without the controlling state shareholder (Russian Institute of Directors, 2014). Partially-owned SOEs have higher disclosure than wholly-owned SOEs. In Russia, SOEs are more sensitive than oligarch-owned enterprises to improved transparency as demonstrated by its effect on fixed investments (Grosman, 2015). Closer ties to foreign multinationals can improve transparency; for example, such ties lead to greater wage reporting in Russian companies (Braguinsky \& Mityakov, 2015).

In China, SOEs face strong incentives to voluntarily disclose additional information to ease investor concerns regarding management quality, the risk of tunneling, and the role of 
government as major shareholder (Wang, Sewon, \& Claiborne, 2008). However, lack of emphasis on efficiency and profitability by state shareholders or their direct access to corporate information might undermine the need for voluntary disclosure. The empirical results are mixed: some demonstrate that the level of voluntary disclosure is positively related to the proportion of state ownership (Wang et al., 2008), particularly for those SOEs with foreign listings (Ferguson, Lam, \& Lee, 2002), while others report no significant relation (Huafang \& Jianguo, 2007) or a negative relation between the two constructs (Xiao, Yang, \& Chow, 2004). There are indications that China's SOEs manage earnings to boost their chances of being selected for IPOs because earnings performance is a government-stated criterion for listing (Aharony, Lee, \& Wong, 2000).

In China, informal institutions often substitute for ineffective formal corporate governance institutions (Ahlstrom, Bruton, \& Yeh, 2008). Both firm owners and local governments are motivated to foster economic growth and both will do whatever necessary to achieve this. This means de facto enforcement of ownership rights and various types of regulation. In contrast, in Russia, formal institutions are undermined through corruption and lack of enforcement and government often does not have mutually complementary goals with large shareholders - there is oftentimes an antagonistic relationship between state and oligarchs with state interventions taking the form of arbitrary inspections and asset stripping aided by lack of court independence (Estrin \& Prevezer, 2010). The Russian government often interferes in business affairs through selectively applying and enforcing formal rules toward firms and owners (Adachi, 2013). 


\section{Executive Compensation}

Studies of executive compensation in SOEs of transition economies are rare. The legacy of communism constrained CEO pay in the early stages of economic reforms (Firth et al., 2006) and there is generally a relatively small pay gap between organization levels in SOEs (Chen, Ezzamel, \& Cai, 2011).The average salary of a manager in a Chinese SOE was only one-fifth of a manager's salary in a foreign MNE, but this gap is closing (Wooldridge, 2012). Pay-forperformance incentive schemes emerged as the profit objective took hold in SOEs. Average CEO compensation nearly doubled in the 1980 s. SOEs controlled by the central government link CEO pay to stock returns and shareholders' wealth, whereas SOEs controlled by local government base performance-related CEO pay on profitability measures (Firth et al., 2006). Initially studies suggested that state ownership in China is negatively associated with cash compensation (Firth et al., 2006; Li, Moshirian, Nguyen, \& Tan, 2007; Adithipyangkul, Alon, \& Zhang, 2009; Conyon \& He, 2008). However, since a new law in 2005 encouraging SOEs to design incentive mechanisms to motivate managers to perform better, managers and directors of SOEs often receive higher compensation than their counterparts at non-SOEs (Jiang \& Kim, 2015).

There may be other influences on executive behavior than compensation. Executive positions in listed SOEs are filled by state bureaucrats rather than professional managers, and are steps in the career of a successful civil servant (Morck et al., 2008). For those with real control but little personal ownership in their company, supporting unprofitable, but politically important projects is a good strategy for career advancement in the state echelons. Executive performance evaluations and promotion decisions are oftentimes still based on whether the managers act in the interests of the Chinese Communist Party (Firth et al., 2006). CEO duality in Chinese SOEs is relatively rare. The board chairman, acting as the legal 
representative of the firm according to the Company Law, is usually appointed by the state as the largest shareholder (Jiang \& Kim, 2015).

In general, governments in transition economies have embraced corporate governance mechanisms based on shareholder rights as an alternative to direct intervention in management of SOEs that was a norm in centrally-planned economies. However, statecontrolled firms in transition economies often lag in adopting best corporate governance practices intended to protect interests of minority shareholders.

\section{DISCUSSION AND FUTURE RESEARCH}

We summarized the range of theories used to study state control in Table 1. While this range is broad, agency theory (Young, Peng, Ahlstrom, Bruton et al., 2008) and, more recently, institutional theory (Child \& Juan, 1997; Suhomlinova, 1999; Puffer \& McCarthy, 2011) are the most used in the context of transition economies. Only a few recent studies on SOEs in transition economies rely on novel theoretical frameworks (e.g., Okhmatovskiy, 2010; Sun, Mellahi, \& Wright, 2012). Further research on SOEs in transition economies should put more emphasis on developing theoretical frameworks that take into account unique challenges faced by state-controlled firms to address questions about state control and corporate governance summarized in Table 5.

Insert Table 5 about here

\section{Means of State Control}

State control over enterprises of strategic importance takes different forms and has different consequences as researchers have just started to explore (Musacchio et al., 2015). Modern 
state capitalism demonstrates more sophisticated forms of state control that adapt to the conditions of a market-based economy. A company with substantial state ownership may adopt certain corporate governance mechanisms that put constraints on state involvement in the corporate governance process and protect interests of other shareholders. Unlike traditional SOEs, modern state-controlled companies in transition economies are often publicly traded and thus state shareholder interests must be reconciled with private shareholder interests, suggesting a need for further research using principal-principal agency theory.

Researchers need to analyze more closely a wide variation of corporate governance configurations in companies under partial state control. The framework of Musacchio et al. (2015) examines under which conditions different forms of state control mitigate the 'liability of stateness' and lead to improved performance. While their work is conceptual, further research can test this framework on data from transition economies to provide fine-grained understanding of state control beyond the state-private dichotomy.

Research on indirect state ownership is scarce, due to limitations of data availability and reliability. More research is needed to explore the shift from direct to indirect forms of state ownership in transition economies. In particular, growing attention has been devoted to Sovereign Wealth Funds (SWFs) (Fotak, Gao, \& Megginson, 2013; Wood \& Wright, 2015; Aguilera, Capape, \& Santiso, forthcoming) but there remains little empirical evidence regarding their control mechanisms as few funds disclose key organizational details. Further, researchers have primarily focused on the impact of SWFs on developed economies (Dewenter, Han, \& Malatesta, 2010), with little attention to their role in emerging economies. Amongst transition economies, SWFs are particularly active in China. Their portfolio organizational structure allows SWFs to have a better separation of management and control thus mitigating the typical principal-principal agency conflict (Young et al., 2008) present in 
state controlled firms. However, SWFs are reluctant to engage in active governance, especially when the portfolio firm is foreign (Fotak et al., 2013). To some extent this lack of involvement alleviates concerns that SWFs may pursue objectives other than profit maximization, such as political objectives or even tunneling (Jiang, Lee, \& Yue, 2010).

We have discussed non-equity mechanisms of political interference but several questions remain unanswered and invite future research. How are different forms of state control and state support interrelated? Can private firms compete with state-supported firms that receive privileged access to financial and other resources? Furthermore, scholars should differentiate between the different geographic regions or administrative levels when studying state control in such large and diverse economies as China and Russia as such studies remain rare.

Dependence on the state creates opportunities for exercising influence beyond firms where the state is a shareholder. Through its leverage over key actors in business groups, the state can exercise influence over other business group members. Growth of such business groups meant that new firms were added to the network of interconnected private and state actors; joining this network brought these firms into the state's sphere of influence (Guthrie, Okhmatovskiy, Schoenman, \& Xiao, 2012). The role of the state in creating and promoting business groups in transition economies deserves more attention among scholars of state capitalism. Transaction cost theory may, for example, yield insights into the effects of such state interference on firm behavior. Conceptual analyses of the relative benefits to private actors of autonomous versus integrated forms of public-private partnerships (Kivleniece \& Quelin, 2012) provide the basis for future empirical studies of private-public governance arrangements in transition economies. Further, the variety of private-public ownership forms we have identified may provide scope for the development of a more contingent approach to private-public sector governance. 
Private and state actors are also connected through networks of political ties (Sun, Mellahi, \& Wright, 2012; Danis, Chiaburu, \& Lyles, 2010). Despite significant progress in building market institutions, political ties continue to play a critical role in transition economies. The political embeddedness perspective emphasizes that connections with politicians serving an instrumental function for the firm can also be leveraged by these politicians to constrain firms' strategic choices, while state control ties also provide firms with an opportunity to influence state actors. Given the prominence of political ties in China and Russia, it is not surprising that most studies about political embeddedness have been conducted in these transition economies (Okhmatovskiy, 2010; Sun, Mellahi, \& Thun, 2010; Sun, Mellahi, Wright, \& Xu, forthcoming). The importance of political connections does not necessarily decline with the development of market institutions (Michelson, 2007; Shi, Markoczy, \& Stan, 2014) because of the impact of multiple contingency factors (Peng \& Zhou, 2005; Sun, Mellahi, \& Wright, 2012). Recent developments emphasize both the roles of political tie heterogeneity (Holburn \& Zelner, 2010; Zheng, Singh, \& Mitchell, 2014) and the interrelationships between personal-level and ownership-related political ties (Kilduff \& Brass, 2010). Further research built upon political embeddedness perspective is needed to examine the implications of these relationships for the governance of firms in transition economies. For example, research might examine how voluntary or forced departures of politically-connected executives and external board members influence governance through changes to the nature of personal versus organizational level political ties.

It is difficult to capture mechanisms of informal influence in empirical studies. Studies have usually relied on self-reported evidence obtained through surveys of top managers (Yakovlev, 2009). Unlike state ownership or state representatives on boards, phone calls from top government officials to CEOs cannot be traced by researchers, but these might be as consequential as formal mechanisms of state control. However, even with limited 
empirical evidence, we can estimate the importance of informal state influence in transition economies as a function of firms' dependence on decisions made by state officials. Preferential treatment and selective punitive actions are frequently observed in transition economies, implying that state officials have plenty of opportunities to exercise influence over firms using informal mechanisms. Further research on such mechanisms is needed to complement existing evidence on formal mechanisms of state control - this is essential for understanding how the state exercises control over firms in transition economies.

\section{Corporate Governance Structures and Processes}

According to the resource-based view (Makhija, 2003; Lazzarini, 2015), an important issue is not just the monitoring role of boards but also the value adding role of directors due to their human and social capital. Research on the role of directors' international experience in transition economies remains limited. Further research is needed on the extent to which transition economy firms recruit overseas directors or expatriates, who can provide the international expertise required. Studies have emphasized the importance of board connections to government agencies, but we have little analysis of the evolution of these relationships. Expectations that the relevance of such social capital would decline over time need to be examined through longitudinal studies of board composition and processes. Important questions concern the extent to which social capital associated with political ties has declined or metamorphosed over time.

There is relatively little analysis of how state involvement on boards affects board processes. Notwithstanding challenges regarding access to board operations, which researchers in developed economies have overcome (Pye, 2013), fine-grained studies of board processes in firms operating with different configurations of state control will likely be 
highly insightful. Finally, studies of board interlocks involving networks of SOEs and private firms (Salvaj \& Couyoumdjian, 2015) could be validated in transition economies.

SOEs can outsource regulation of corporate governance practices to developed economies by listing on foreign exchanges or by acquiring foreign assets. Several studies on cross-listings of foreign firms on Western exchanges observe improved corporate governance standards and performance of foreign firms as they 'bond' to a better governance and regulatory regime (Khanna, Palepu, \& Srinivasan, 2004; Ferguson et al., 2002; Bell, Filatotchev, \& Aguilera, 2014), but more empirical research is needed to test the boundaries of bonding theory in the context of SOEs in transition economies. As more SOEs from transition economies get listed on foreign exchanges, future studies could explore corporate governance impact across institutional regimes of these stock exchanges. For example, how does the selection of market tier between main, secondary or lower tier impact SOE's corporate governance? Would listing on London Stock Exchange improve corporate governance of an SOE in the same way as listing under a different corporate governance regime, such as Singapore Exchange or Frankfurt Stock Exchange? Institutional analysis would help differentiate between formal stock exchange rules and informal rules or enforcement mechanisms that firms are subject to in practice. Such analysis could be linked to internationalization of SOEs through FDI, acquisitions or joint ventures (Liang et al., 2015; Choudhury \& Khanna, 2014; Lu, Liu, Wright, \& Filatotchev, 2014; Li, Cui, \& Lu, 2014; Meyer, Ding, Li, \& Zhang, 2014; Brouthers \& Bamossy, 1997; White, 2000; Zeng, Douglas, $\& \mathrm{Wu}, 2013)$ as moderating effects of foreign listings. Further, the role of foreign MNEs entering transition economies as agents of change in state control and corporate governance (Meyer \& Lieb-Doczy, 2003) may be a fruitful avenue to explore.

Outsourcing corporate governance regulation may increase accountability and transparency as most SOEs adopted IFRS standards and appointed international audit firms 
(Grosman \& Leiponen, 2013). Researchers could compare transparency and disclosure practices of SOEs in transition economies and developed economies using institutional theory since the nature of such practices may be affected by institutional environment. Specific areas for study might include misrepresenting financial results or withholding information about shareholders' identities and board members' backgrounds and affiliations (Puffer \& McCarthy, 2011).

There is a shortage of research on Top Management Team (TMT) selection and compensation in SOEs, primarily due to data scarcity and non-disclosure. However, we see the following trends emerging regarding TMT selection mechanisms: 1) appointment of trusted state officials to top management positions, making them ultra-powerful state 'nominees'; 2) appointments of the new generation of sophisticated managers who learned about business in the world's best business schools, worked abroad and were exposed to better governance practices and business ethics than their predecessors (Wooldridge, 2012). However, the latter category of managers may only fulfill technical or operational roles, with decision making being made at the level of state shareholder.

Future studies should consider how SOEs can attract new talent given competition with compensation and benefits offered by domestic private firms and MNEs. Further research can explore how equity-linked long-term incentives of top managers influence decision making at SOEs. A formal theory is needed to distinguish the use of equity-linked compensation to solve principal-agent problems from the use of such compensation to resolve conflicting interests of state and private shareholders. 


\section{Contextual Factors}

Transition economies were not homogeneous in 1989 and are even less homogeneous now. Some have progressed to become EU members, while others have progressed little or even regressed after initial reforms. This variety is vividly illustrated in Hoskisson et al.'s (2013) analysis that categorizes emerging economies, including transition economies, into five different clusters according to their institutional and infrastructure development. Further research is needed to analyze the relationships between the evolution of state control and institutional development. For example, recent studies demonstrate how home country institutional contextual factors complement or substitute for director human and social capital (Lu et al., 2014) and there is a need to apply this analysis to the role of state directors.

In transition economies, managers have relied excessively on informal institutions due to weak formal institutions. Continuing reliance on informal institutions under conditions of formal institutional voids creates major obstacles for badly needed reforms (Puffer \& McCarthy, 2011). A specific contextual issue requiring further analysis concerns the problem of corruption in the governance of firms with some element of state control. Governments in transition economies have made moves to tackle corruption by removing and imprisoning implicated government officials, often after changes in ruling cliques. Such changes will affect firms closely connected to the former officials. Analyses of the effects of removing corrupt officials and politicians on the firms closely associated with them would likely yield interesting insights. Such issues suggest scope for the development and application of political embeddedness and institutional perspectives.

\section{CONCLUSION}

Twenty five years on from 1989, SOEs in transition economies are far from the centrallyplanned behemoths and state control has evolved into different organizational and 
governance forms. Recent studies on state controlled firms in transition economies, other than China and Russia, are rare. This omission is unfortunate since these economies have become more diverse and continue to change. We encourage context-specific research on SOEs to understand the evolution of state control in particular countries, as well as comparative research, which can provide insights into whether state capitalism varies between transition economies. If so, insights generated are context-bound. Both context-specific and comparative studies could provide opportunities to extend mainstream theory by examining interfaces between theory and context, by both contextualizing theory and theorizing about context. With this review, we lay the foundation for such further examination.

\section{ACKNOWLEDGMENTS}

We gratefully acknowledge constructive and insightful comments provided by Ruth Aguilera, Guest Editor for this special issue, and the anonymous reviewers. 


\section{REFERENCES}

Adachi, Y. 2013. Building big business in Russia: The impact of informal corporate governance practices. London: Routledge.

Adithipyangkul, P., Alon, I., \& Zhang, T., 2011. Executive perks: Compensation and corporate performance in China. Asia Pacific Journal of Management, 28(2): 401-425.

Aguilera, R. V., Capapé, J., \& Santiso, J. Sovereign wealth funds: A strategic governance view. Academy of Management Perspectives, forthcoming.

Aharoni, Y. 1986. The evolution and management of state owned enterprises. Cambridge, MA: Ballinger Publishing Company.

Aharony, J., Lee, J., \& Wong, T. 2000. Financial packaging of IPO firms in China. Journal of Accounting Research, 38(1): 103-126.

Ahlstrom, D., Bruton, G. D., \& Yeh, K. S. 2008. Private firms in China: Building legitimacy in an emerging economy. Journal of World Business, 43(4): 385-399.

Bell, G., Filatotchev, I., \& Aguilera, R. 2014. Corporate governance and investors' perceptions of foreign IPO value: An institutional perspective. Academy of Management Journal, 57(1): 301-320.

Black, B., Kraakman, R., \& Tarassova, A. 2000. Russian privatization and corporate governance: what went wrong? Stanford Law Review, 52(6): 1731-1808.

Boisot, M., \& Child, J. 1996. From fiefs to clans and network capitalism: Explaining China's emerging economic order. Administrative Science Quarterly, 41(4): 600-628.

Boycko, M., Shleifer, A., \& Vishny, R. W. 1995. Privatizing Russia. Boston: MIT Press Books.

Braguinsky, S. 2009. Postcommunist oligarchs in Russia: Quantitative analysis. Journal of Law and Economics, 52(2): 307-349.

Braguinsky, S., \& Mityakov, S. 2015. Foreign corporations and the culture of transparency: Evidence from Russian administrative data. Journal of Financial Economics, 117(1): 139164.

Brouthers, K. D., \& Bamossy, G. J. 1997. The role of key stakeholders in international joint venture negotiations: Case studies from Eastern Europe. Journal of International Business Studies, 28(2): 285-308.

Bruton, G., Peng, M., Ahlstrom, D., Stan, C., \& Xu, K. 2015. State-owned enterprises as hybrid organizations. The Academy of Management Perspectives, 29(1): 92-114.

Cao, Y., Qian, Y., \& Weingast, B. R. 1999. From federalism, Chinese style to privatization, Chinese style. Economics of Transition, 7(1): 103-131.

Chen, J., Ezzamel, M., \& Cai, Z. 2011. Managerial power theory, tournament theory, and executive pay in China. Journal of Corporate Finance, 17(4): 1176-1199.

Chen, T., 2015. Institutions, board structure, and corporate performance: evidence from Chinese firms. Journal of Corporate Finance, 32: 217-237.

Chernykh, L. 2008. Ultimate ownership and control in Russia. Journal of Financial Economics, 88(1): 169-192.

Chernykh, L. 2011. Profit or politics? Understanding renationalizations in Russia. Journal of Corporate Finance, 17(5): 1237-1253.

Child, J., \& Yuan, L. 1996. Institutional constraints on economic reform: The case of investment decisions in China. Organization Science, 7(1): 60-77.

Choudhury, P., \& Khanna, T. 2014. Toward resource independence - Why state-owned entities become multinationals: An empirical study of India's public R\&D laboratories. Journal of International Business Studies, 45(8): 943-960.

Claessens, S., \& Djankov, S. 1999. Ownership concentration and corporate performance in the Czech Republic. Journal of Comparative Economics, 27(3): 498-513. 
Clarke, D. C. 2006. Independent directors in Chinese corporate governance. Delaware Journal Corporate Law, 31(1):125-228.

Conyon, M. J., \& He, L. 2011. Executive compensation and corporate governance in China. Journal of Corporate Finance, 17(4): 1158-1175.

Cull, R., Li, W., Sun, B., \& Xu, L. C. 2015. Government connections and financial constraints: evidence from a large representative sample of Chinese firms. Journal of Corporate Finance, 32: 271-294.

Danis, W. M., Chiaburu, D. S., \& Lyles, M. A. 2010. The impact of managerial networking intensity and market-based strategies on firm growth during institutional upheaval: A study of small and medium sized enterprises in a transition economy. Journal of International Business Studies, 41(2): 287-307.

Delios, A., Wu, Z. J., \& Zhou, N. 2006. A new perspective on ownership identities in China's listed companies. Management and Organization Review, 2(3): 319-343.

Deng, Y., Morck, R., Wu, J., \& Yeung, B. 2015. China's pseudo-monetary policy. Review of Finance, 19(1): 55-93.

Dewenter, K. L., \& Malatesta, P. H. 2001. State-owned and privately owned firms: An empirical analysis of profitability, leverage, and labor intensity. American Economic Review, 91(1): 320-334.

Dewenter, K. L., Han, X., \& Malatesta, P. H. 2010. Firm values and sovereign wealth fund investments. Journal of Financial Economics, 98(2): 256-278.

Djankov, S., \& Murrell, P. 2002. Enterprise restructuring in transition: A quantitative survey. Journal of Economic Literature, 40(3): 739-792.

Enikolopov, R. \& Stepanov, S. 2013. Corporate governance in Russia, in: Alexeev, M., \& Weber, S. (Eds.). The Oxford handbook of the Russian economy: 221-245. Oxford: OUP.

Estrin, S., \& Prevezer, M. 2010. A survey on institutions and new firm entry: How and why do entry rates differ in emerging markets? Economic Systems, 34(3): 289-308.

Estrin, S., \& Wright, M. 1999. Corporate governance in the former Soviet Union: An overview. Journal of Comparative Economics, 27(3): 398-421.

Fan, J. P., Wong, T. J., \& Zhang, T. 2007. Politically connected CEOs, corporate governance, and post-IPO performance of China's newly partially privatized firms. Journal of Financial Economics, 84(2): 330-357.

Ferguson, M. J., Lam, K. C., \& Lee, G. M. 2002. Voluntary disclosure by state-owned enterprises listed on the stock exchange of Hong Kong. Journal of International Financial Management \& Accounting, 13(2): 125-152.

Fernandez-Stembridge, L., \& Fernandez, J. A. 2007. China's state owned enterprise reforms: An industrial and CEO approach. London: Routledge.

Ferrarini, G. A., \& Filippelli, M. 2014. Independent directors and controlling shareholders around the world. European Corporate Governance Institute (ECGI)-Law Working Paper, (258).

Filatotchev, I., Buck, T., \& Zhukov, V. 2000. Downsizing in privatized firms in Russia, Ukraine, and Belarus. Academy of Management Journal, 43(3): 286-304.

Filatotchev, I., Wright, M., \& Bleaney, M. 1999. Privatization, insider control and managerial entrenchment in Russia. Economics of Transition, 7(2): 481-504.

Firth, M., Fung, P. M., \& Rui, O. M. 2006. Corporate performance and CEO compensation in China. Journal of Corporate Finance, 12(4): 693-714.

Forbes. 2015. Inside the 2015 Forbes billionaires list: Facts and figures. Retrieved on 29.08.2015, from http://www.forbes.com/sites/kerryadolan/2015/03/02/inside-the-2015-forbesbillionaires-list-facts-and-figures/.

Fotak, V., Gao, J. \& Megginson, W. L. 2013. The financial role of sovereign wealth funds, in M. Wright, D. Siegel, K. Keasey and I. Filatotchev (Eds.), The Oxford Handbook of Corporate Governance: 581-604. Oxford: OUP. 
Frydman, R., Gray, C., Hessel, M., \& Rapaczynski, A. 1999. When does privatization work? The impact of private ownership on corporate performance in the transition economies. Quarterly Journal of Economics, 114(4): 1153-1191.

Frye, T. 2002. Capture or exchange? Business lobbying in Russia. Europe-Asia Studies, 54(7): 1017-1036.

Frye, T. M., \& Iwasaki, I. 2011. Government directors and business-state relations in Russia. European Journal of Political Economy, 27(4): 642-658.

Guriev, S., \& Rachinsky, A. 2005. The role of oligarchs in Russian capitalism. Journal of Economic Perspectives, 19(1): 131-150.

Granrose, C.S., Huang, Q., \& Reigadas, E. 2000. Changing organizational cultures in Chinese firms, in Ashkanasy, N.M., Wilderom, C.P.M., \& Peterson, M.F. (Eds.), Handbook of Organizational Culture and Climate: 483-496. Thousand Oaks, CA: Sage.

Grosman, A. 2015. Corporate governance as a mechanism to mitigate financing constraints on investment. Working paper, available at http://ssrn.com/abstract $=2638434$.

Grosman, A., \& Leiponen, A. 2013. Who is monitoring the monitor? The influence of ownership networks and organizational transparency on long-term resource commitment in Russian listed firms. Academy of Management Proceedings, 1: 17171.

Grosman, A., \& Wright, M. 2015. The good, the great and the independent: Implications of board and ownership structures on investment. Academy of Management Proceedings.

Groves, T., Hong, J., McMillan, J., \& Naughton, B. 1994. Autonomy and incentives in Chinese state enterprises. Quarterly Journal of Economics, 109(1): 183- 209.

Guthrie, D., Okhmatovskiy, I., Schoenman, R., \& Xiao, Z. 2012. Ownership networks and new institutional forms in transition from plan to market, in B. Kogut (Ed.), The small worlds of corporate governance: $117-149$. Cambridge, MA: MIT Press.

Hanson, P., \& Teague, E. 2005. Big business and the state in Russia. Europe-Asia Studies, 57(5): 657-680.

Hashi, I., Welfens, P. J., \& Wziatek-Kubiak, A. (Eds.). 2007. Industrial competitiveness and restructuring in enlarged Europe: How accession countries catch up and integrate in the European Union. Basingstoke: Palgrave Macmillan.

Haveman, H. A., \& Wang, Y. 2013. Going (more) public: Institutional isomorphism and ownership reform among Chinese firms. Management and Organization Review, 9(1): 17-51.

Havrylyshyn, O. 2005. Divergent paths in post-communist transformation: Capitalism for all or capitalism for the few? Basingstoke: Palgrave Macmillan.

Hellman, J.S., Jones, G., \& Kaufmann, D. 2003. Seize the state, seize the day: State capture and influence in transition economies. Journal of Comparative Economics, 31 (4): 751-773.

Holburn, G. L. F. \& Zelner, B. A. 2010. Political capabilities, policy risks, and international investment strategy: Evidence from the global electric power generation industry. Strategic Management Journal, 31(12): 1290-1315.

Hoskisson, R. E., Eden, L., Lau, C. M. \& Wright, M. 2000. Strategy in emerging economies. Academy of Management Journal, 43(3): 249-267.

Hoskisson, R. E., Wright, M., Filatotchev, I., \& Peng, M. W. 2013. Emerging multinationals from mid-range economies: The influence of institutions and factor markets. Journal of Management Studies, 50(7): 1295-1321.

Huafang, X., \& Jianguo, Y. 2007. Ownership structure, board composition and corporate voluntary disclosure: Evidence from listed companies in China. Managerial Auditing Journal, 22(6): 604-619.

Inoue, C., Lazzarini, S., \& Musacchio, A. 2013. Leviathan as a minority shareholder: Firm-level implications of equity purchases by the state. Academy of Management Journal, 56(6): 1775-1801. 
Jiang, F., \& Kim, K. A. 2015. Corporate governance in China: A modern perspective. Journal of Corporate Finance, 32: 190-216.

Jiang, G., Lee, C. M., \& Yue, H. 2010. Tunneling through intercorporate loans: The China experience. Journal of Financial Economics, 98(1): 1-20.

Khanna, T., Palepu, K. G., \& Srinivasan, S. 2004. Disclosure practices of foreign companies interacting with US markets. Journal of Accounting Research, 42(2): 475-508.

Kilduff, M. \& Brass, D. J. 2010. Organizational social network research: Core ideas and key debates. Academy of Management Annals, 4(1): 317-357.

Kivleniece, I., \& Quelin, B.V. 2012. Creating and capturing value in public-private ties: A private actor's perspective. Academy of Management Review, 37(2): 272-299.

Kočenda, E., \& Hanousek, J. 2012. State ownership and control in the Czech Republic. Economic Change and Restructuring, 45(3), 157-191.

Lane, D. S., \& Myant, M. R. (Eds.). 2007. Varieties of capitalism in post-communist countries. Basingstoke: Palgrave Macmillan.

Lau, L. J., Qian, Y., \& Roland. G. 2000. "Reform without losers: An interpretation of China's dualtrack approach to transition.” Journal of Political Economy, 108(1): $120-143$.

Lazzarini, S. G. 2015. Strategizing by the government: Can industrial policy create firm-level competitive advantage? Strategic Management Journal, 36(1): 97-112.

Li, D., Moshirian, F., Nguyen, P., \& Tan, L. W. 2007. Corporate governance or globalization: What determines CEO compensation in China? Research in International Business and Finance, 21(1): 32-49.

Li, M. H., Cui, L., \& Lu, J. 2014. Varieties in state capitalism: Outward FDI strategies of central and local state-owned enterprises from emerging economy countries. Journal of International Business Studies, 45(8): 980-1004.

Liang, H., Ren, B., \& Sun, S. L. 2015. An anatomy of state control in the globalization of stateowned enterprises. Journal of International Business Studies, 46(2): 223-240.

Lin, K.J., Tan, J., Zhao, L., \& Karim, K., 2015. In the name of charity: Political connections and strategic corporate social responsibility in a transition economy. Journal of Corporate Finance, 32: 327-346.

Liu, J., \& Pissler, K., B. 2013. China - Corporate governance of business organizations, in A. M. Fleckner \& K. J. Hop (Eds.), Comparative corporate governance: A functional and international analysis: pp. 156-207, Cambridge: Cambridge University Press.

Liu, Q., \& Lu, Z. J. 2007. Corporate governance and earnings management in Chinese listed companies: A tunneling perspective. Journal of Corporate Finance, 13: 881-906.

Liu, Y., Miletkov, M. K., Wei, Z., \& Yang, T. 2015. Board independence and firm performance in China. Journal of Corporate Finance, 30: 223-244.

Lu, J., Liu, X., Wright, M., \& Filatotchev, I. 2014. International experience and FDI location choices of Chinese firms: The moderating effects of home country government support and host country institutions, Journal of International Business Studies, 45(4): 428-449.

Makhija, M. 2003. Comparing the resource-based and market-based views of the firm: empirical evidence from Czech privatization. Strategic Management Journal, 24(5): 433-452.

Megginson, W. L., \& Netter, J. M. 2001. From state to market: A survey of empirical studies on privatization. Journal of Economic Literature, 39(2): 321-389.

Melkumov, D. 2009. Institutional background as a determinant of boards of directors' internal and external roles: The case of Russia. Journal of World Business, 44(1): 94-103.

Meyer, K. E., Ding, Y., Li, J., \& Zhang, H. 2014. Overcoming distrust: How state-owned enterprises adapt their foreign entries to institutional pressures abroad. Journal of International Business Studies, 45(8): 1005-1028.

Meyer, K.E. \& Lieb-Doczy, E. 2003. Post-acquisition restructuring as evolutionary process, Journal of Management Studies, 40(2): 459-482. 
Michelson, E. 2007. Lawyers, political embeddedness, and institutional continuity in China's transition from socialism. American Journal of Sociology, 113(2): 352-414.

Mickiewicz, T. 2010. Economics of institutional change: Central and Eastern Europe. Basingstoke: Palgrave Macmillan.

Morck, R., Yeung, B., \& Zhao, M. 2008. Perspectives on China's outward foreign direct investment. Journal of International Business Studies, 39(3): 337-350.

Musacchio, A., Lazzarini, S., \& Aguilera, R. 2015. New varieties of state capitalism: Strategic and governance implications. The Academy of Management Perspectives, 29(1): 115-131.

Nolan, P. 2001. China and the global economy: National champions, industrial policy and the big business revolution. London: Palgrave Macmillan.

Okhmatovskiy, I. 2010. Performance implications of ties to the government and SOEs: A political embeddedness perspective. Journal of Management Studies, 47(6): 1020-1047.

Pahor, M., Prasnikar, J. \& Ferligoj, A. 2004. Building a corporate network in a transition economy: The case of Slovenia. Post-Communist Economies, 16(3): 307-31.

Peng, M. W., \& Zhou, J. Q. 2005. How network strategies and institutional transitions evolve in Asia. Asia Pacific Journal of Management, 22(4): 321-336.

Pistor, K., \& Turkewitz, J. 1996. Coping with Hydra: State ownership after privatization, in R. Frydman, C. W. Gray, \& A. Rapaczynski (Eds.), Corporate governance in Central Europe and Russia: 192-246. Budapest, London, New York: CEU Press.

Puffer, S. M., \& McCarthy, D. J. 2007. Can Russia's state-managed, network capitalism be competitive? Institutional pull versus institutional push. Journal of World Business, 42(1): $1-13$.

Puffer, S. M., \& McCarthy, D. J. 2011. Two decades of Russian business and management research: An institutional theory perspective. The Academy of Management Perspectives, 25(2): 2136.

Pugliese, A., Bezemer, P. J., Zattoni, A., Huse, M., Van den Bosch, F. A., \& Volberda, H. W. 2009. Boards of directors' contribution to strategy: A literature review and research agenda. Corporate Governance: An International Review, 17(3): 292-306.

Pye, A. 2013. Boards and governance: 25 years of qualitative research with directors of FTSE companies, in Wright, M., Siegel, D., Keasey, K. \& Filatotchev, I. (Eds.). Oxford Handbook of Corporate Governance: 135-162. Oxford: OUP.

Qian, M., \& Yeung, B. 2015. Bank financing and corporate governance. Journal of Corporate Finance, 32: 258-270.

Radygin, A. 2008. State capitalism and the financial crisis: Interdependence, inefficiencies, and future directions (in Russian). Economic Policy, 6: 88-105.

Radygin, A., Entov, R., Gontmakher, A., Mezheraups, I., \& Turuntseva, M. 2004. Economic and legal factors and constraints to the emergence of corporate governance models (in Russian). Institute of Economics of Transition Working Paper No. 7. IET, Moscow.

Ralston, D. A., Terpstra-Tong, J., Terpstra, R. H., Wang, X., \& Egri, C. 2006. Today's state-owned enterprises of China: Are they dying dinosaurs or dynamic dynamos? Strategic Management Journal, 27(9): 825-843.

Ramamurti, R., \& Vernon, R. (Eds.). 1991. Privatization and control of state-owned enterprises. Washington, DC: The World Bank.

Russian Institute of Directors (RID). 2014. A study of corporate governance practices in SOEs during the 2008 - 2013 period (in Russian). Moscow: RID.

Salvaj, E., \& Couyoumdjian, J. P. 2015. Interlocked business groups and the state in Chile (19702010). Business History, (ahead-of-print), 1-20.

Seglen, P. O. 1994. Causal Relationship between article citedness and journal impact factor, Journal of the America Society for Information Science, 45(1): 1-11. 
Sheng, H., \& Zhao, N. 2013. China's state-owned enterprises: Nature, performance and reform. Singapore: World Scientific.

Shi, W., Markoczy, L., \& Stan, C. V. 2014. The continuing importance of political ties in China. Academy of Management Perspectives, 28(1): 57-75.

Simachev, Y. V., \& Kuzyk, M. G. 2012. Anti-crisis state intervention in the Russian economy: Support and limitations (in Russian). Journal of the New Economic Association, 1(13): 100125.

Spicer, A., \& Okhmatovskiy, I. 2015. Multiple paths to institutional-based trust production and repair: Lessons from the Russian bank deposit market. Organization Studies, 36(9): 11431170.

Spicer, A., McDermott, G. \& Kogut, B. 2000. Entrepreneurship and privatization in Central Europe: The tenuous balance between destruction and creation. Academy of Management Review, 25(3): 630-649.

Stark, D. 1996. Recombinant property in East European capitalism. American Journal of Sociology, 101(4): 993-1027.

Suhomlinova, O. O. 1999. Constructive destruction: Transformation of Russian state-owned construction enterprises during market transition. Organization Studies, 20(3): 451-483.

Sun, P., Mellahi, K., \& Thun, E. 2010. The dynamic value of MNE political embeddedness: The case of the Chinese automobile industry. Journal of International Business Studies, 41(7): 11611182.

Sun, P., Mellahi, K., \& Wright, M. 2012. The contingent value of corporate political ties. Academy of Management Perspectives, 26(3): 68-82.

Sun, P., Mellahi, K., Wright, M., \& Xu, H. Political tie heterogeneity and the impact of adverse shocks on firm value. Journal of Management Studies, forthcoming.

Thun, E. 2004. Industrial policy, Chinese style: FDI, regulation, and dreams of national champions in the auto sector. Journal of East Asian Studies, 4(3): 453-489.

Uhlenbruck, K., Meyer, K. E., \& Hitt, M. A. 2003. Organizational transformation in transition economies: Resource-based and organizational learning perspectives. Journal of Management Studies. 40(2): 257-282.

Wang, J., Guthrie, D., \& Xiao, Z. 2011. The rise of SASAC: Asset management, ownership concentration, and firm performance in China's capital markets. Management and Organization Review, 8(2): 253-281.

Wang, K., Sewon, O., \& Claiborne, M. C. 2008. Determinants and consequences of voluntary disclosure in an emerging market: Evidence from China. Journal of International Accounting, Auditing and Taxation, 17(1): 14-30.

Wank, D. L. 1995. Private business, bureaucracy, and political alliance in a Chinese city. Australian Journal of Chinese Affairs, 33: 55-71.

White, S. 2000. Competition, capabilities, and the make, buy, or ally decisions of Chinese stateowned firms. Academy of Management Journal, 43(3): 324-341.

Wood, G., \& Wright, M. 2015. Corporations and new statism: Trends and research priorities. Academy of Management Perspectives, 29(2): 271-286.

Wooldridge, A. 2012. The visible hand. The Economist, January, 21. http://www.economist.com/node/21542931. Accessed March 3, 2015.

Wright, M., Buck, T. and Filatotchev, I. 1998. Bank and investment fund monitoring of privatized firms in Russia. Economics of Transition, 6(2): 361-387.

Xiao, J. Z., Yang, H., \& Chow, C. W. 2004. The determinants and characteristics of voluntary Internet-based disclosures by listed Chinese companies. Journal of Accounting and Public Policy, 23(3): 191-225.

Yakovlev, A. A. 2006. The evolution of business - state interaction in Russia: From state capture to business capture? Europe-Asia Studies, 58 (7): 1033 - 1056. 
Yakovlev, A. A. 2009. State-business relations and improvement of corporate governance, in Dolgopyatova, T., Iwasaki, I., \& Yakovlev, A. A. (Eds.). Organization and Development of Russian Business: A Firm-level Analysis: 284-306. Basingstoke: Palgrave Macmillan.

Young, M. N., Peng, M. W., Ahlstrom, D., Bruton, G. D. \& Jiang, Y. 2008. Corporate Governance in Emerging Economies: A Review of the Principal-Principal Perspective. Journal of Management Studies, 45 (1): 196-220.

Zeng, Y., Douglas, T. J., \& Wu, C. 2013. The seller's perspective on determinants of acquisition likelihood: Insights from China's beer industry. Journal of Management Studies, 50(4): 673698.

Zhao, Y. 2011. Review of the incentive system of independent directors in China. Business Law International, 12: 215-233.

Zheng, W., Singh, K., \& Mitchell, W. 2014. Buffering and enabling: The impact of interlocking political ties on firm survival and sales growth. Strategic Management Journal, online version, DOI: $10.1002 / \mathrm{smj} .2301$.

Zhu, X. 2012. Understanding China's growth: Past, present, and future, Journal of Economic Perspectives, 26(4): 103-124.

Anna Grosman is Assistant Professor of Corporate Finance at Aston Business School. She graduated from Dauphine University with an MSc in Business Administration, from Panthéon-Assas University with an MSc in International Business, and from Imperial College London with a $\mathrm{PhD}$ in Corporate Finance. Her main fields of research are corporate governance, corporate finance and transition economies. She was previously Director of Corporate Development at Koch Industries' GeorgiaPacific, and worked in corporate finance at Citigroup.

Ilya Okhmatovskiy is Assistant Professor of Strategy and Organization at the Desautels Faculty of Management, McGill University. He received PhD in Business Administration from Marshall School of Business at the University of Southern California. His research about corporate governance standards and about performance implications of ties with the state has been published in the Journal of Management Studies, Organization Science, and Organization Studies.

Mike Wright is Professor of Entrepreneurship, Head of the Innovation and Entrepreneurship Department, Director of the Centre for Management Buyout Research and Associate Director of the Enterprise Research Centre at Imperial College Business School. He is also a visiting professor at the University of Ghent. His research focuses on corporate governance, private equity, entrepreneurial mobility and emerging economies on which he has published in many leading journals. He is an editor of Strategic Entrepreneurship Journal and Academy of Management Perspectives. 
TABLE 1

Positive and Negative Effects of State Control According to Different Theoretical Perspectives

\begin{tabular}{|c|c|c|c|c|}
\hline $\begin{array}{l}\text { Theoretical } \\
\text { perspective }\end{array}$ & $\begin{array}{l}\text { Negative effects of state } \\
\text { control }\end{array}$ & $\begin{array}{l}\text { Forms of state control that can } \\
\text { minimize its negative effects }\end{array}$ & Positive effects of state control & $\begin{array}{l}\text { Forms of state control that can } \\
\text { maximize its positive effects }\end{array}$ \\
\hline Agency theory & $\begin{array}{l}\text { State as principal provides } \\
\text { weak monitoring. Not clear } \\
\text { who acts as principal on } \\
\text { behalf of state. Soft budget } \\
\text { constraints create weak } \\
\text { incentives for managers as } \\
\text { agents. }\end{array}$ & $\begin{array}{l}\text { Active state involvement in CG. } \\
\text { Creation of asset management } \\
\text { companies to manage state assets } \\
\text { defines principal responsible for } \\
\text { monitoring. Firms with partial state } \\
\text { ownership benefit from diligent } \\
\text { monitoring by private investors. }\end{array}$ & $\begin{array}{l}\text { Under conditions of entrenched } \\
\text { management and diffused ownership, } \\
\text { state shareholders can exercise } \\
\text { influence over management even } \\
\text { with relatively small stake. }\end{array}$ & $\begin{array}{l}\text { State ownership accompanied by CG } \\
\text { mechanisms enabling effective control. }\end{array}$ \\
\hline $\begin{array}{l}\text { Transaction cost } \\
\text { economics }\end{array}$ & $\begin{array}{l}\text { State control increases costs } \\
\text { of transacting by increasing } \\
\text { risk that firm may not fulfill } \\
\text { contract obligations due to } \\
\text { politically motivated } \\
\text { interference. }\end{array}$ & $\begin{array}{l}\text { Partial state ownership gives private } \\
\text { shareholders enough influence to } \\
\text { prevent unilateral decision-making by } \\
\text { state shareholders. Indirect state } \\
\text { ownership isolates political actors } \\
\text { from direct involvement in CG. }\end{array}$ & $\begin{array}{l}\text { State control decreases costs of } \\
\text { transacting by reducing risk of } \\
\text { fraudulent behavior on behalf of } \\
\text { firms. }\end{array}$ & $\begin{array}{l}\text { State ownership accompanied by CG } \\
\text { mechanisms enabling active } \\
\text { involvement of state shareholders in } \\
\text { monitoring. }\end{array}$ \\
\hline $\begin{array}{l}\text { Institutional } \\
\text { theory }\end{array}$ & $\begin{array}{l}\text { Performing simultaneously } \\
\text { functions of regulator and } \\
\text { owner of economic actors } \\
\text { creates conflicts of interest. }\end{array}$ & $\begin{array}{l}\text { Isolating state agencies acting as } \\
\text { shareholders from state agencies } \\
\text { acting as regulators. }\end{array}$ & $\begin{array}{l}\text { State control solves some problems } \\
\text { associated with institutional voids. } \\
\text { State leverages control over firms } \\
\text { when acting as "institutional } \\
\text { entrepreneur". }\end{array}$ & $\begin{array}{l}\text { State ownership accompanied by CG } \\
\text { mechanisms enabling monitoring. } \\
\text { Regulations enabling "institutional } \\
\text { entrepreneurship" by state-controlled } \\
\text { firms. }\end{array}$ \\
\hline $\begin{array}{l}\text { Industrial policy } \\
\text { perspective }\end{array}$ & $\begin{array}{l}\text { More opportunities for } \\
\text { corruption. Obstacles created } \\
\text { for independent firms } \\
\text { competing with state- } \\
\text { supported industry } \\
\text { champions. }\end{array}$ & $\begin{array}{l}\text { Partial state ownership gives private } \\
\text { shareholders influence to prevent } \\
\text { unilateral decision-making by state } \\
\text { shareholders. Regulations that protect } \\
\text { private firms in industries dominated } \\
\text { by state-supported firms. }\end{array}$ & $\begin{array}{l}\text { State control enables implementation } \\
\text { of industrial policy through } \\
\text { coordination of investments made by } \\
\text { state-supported industry champions. }\end{array}$ & $\begin{array}{l}\text { Transparent CG mechanisms to be used } \\
\text { by the state for coordinating firms } \\
\text { receiving state support. }\end{array}$ \\
\hline $\begin{array}{l}\text { Resource-based } \\
\text { view }\end{array}$ & $\begin{array}{l}\text { Endowment with state } \\
\text { resources makes state- } \\
\text { controlled firms reluctant to } \\
\text { develop skills to obtain these } \\
\text { resources without state } \\
\text { support. }\end{array}$ & $\begin{array}{l}\text { Providing managers of state- } \\
\text { controlled firms with sufficient } \\
\text { autonomy and creating strong } \\
\text { incentives to focus on increasing } \\
\text { competitiveness of their firms. }\end{array}$ & $\begin{array}{l}\text { State-controlled firms benefit from } \\
\text { access to valuable resources } \\
\text { belonging to state. }\end{array}$ & $\begin{array}{l}\text { CG mechanisms engaging state as } \\
\text { shareholder increase chances of gaining } \\
\text { access to state resources. Regulation that } \\
\text { constrains potential corruption } \\
\text { associated with distribution of these } \\
\text { resources. }\end{array}$ \\
\hline
\end{tabular}




\begin{tabular}{|l|l|l|l|l|}
\hline $\begin{array}{l}\text { Political } \\
\text { embeddedness } \\
\text { perspective }\end{array}$ & $\begin{array}{l}\text { Political connections that } \\
\text { firms use to obtain benefits } \\
\text { from the state also constrain } \\
\text { firms' strategic choices. }\end{array}$ & $\begin{array}{l}\text { Formalization of state expectations } \\
\text { and high transparency of governance } \\
\text { process limit politicians' ability to } \\
\text { exercise informal influence over } \\
\text { firms' strategic choices. }\end{array}$ & $\begin{array}{l}\text { Political connections facilitate firms' } \\
\text { access to valuable resources } \\
\text { controlled by state. }\end{array}$ & $\begin{array}{l}\text { Formalization of state commitment to } \\
\text { provide state-affiliated firms with } \\
\text { privileged access to resources. } \\
\text { Regulation that constrains potential } \\
\text { corruption associated with distribution } \\
\text { of state resources. }\end{array}$ \\
\hline
\end{tabular}


TABLE 2

Summary of Key Studies Representing Different Theoretical Perspectives

\begin{tabular}{|c|c|c|c|c|c|}
\hline & Author(s) (Year) & Theory & Data & Key findings & $\begin{array}{l}\text { Empirical } \\
\text { setting }\end{array}$ \\
\hline 1. & $\begin{array}{l}\text { Sun, Mellahi, } \\
\text { Wright \& Xu } \\
\text { (forthcoming) }\end{array}$ & $\mathrm{PE}$ & $\begin{array}{l}154 \text { firms listed on Hong Kong, Shanghai, } \\
\text { and Shenzhen stock exchanges. Event } \\
\text { study analysis surrounding removal of the } \\
\text { Communist Party Chief in Shanghai in } \\
2006 .\end{array}$ & $\begin{array}{l}\text { An unanticipated high profile political event triggers a negative } \\
\text { stock market evaluation effect of managerial ties to municipal } \\
\text { government, but the effect of government ownership ties is } \\
\text { insignificant. Companies combining managerial and ownership } \\
\text { ties experienced less post-shock reduction in market value than } \\
\text { those holding only managerial political ties. }\end{array}$ & China \\
\hline 2. & Chen (2015) & AT & $\begin{array}{l}\text { World Bank survey of } 2,400 \text { public and } \\
\text { private firms across } 18 \text { Chinese cities } \\
2003 \text {. }\end{array}$ & $\begin{array}{l}\text { Weaker helping hand from government associated with higher } \\
\text { number and proportion of outsiders on board. }\end{array}$ & China \\
\hline 3. & $\begin{array}{l}\text { Cull, Li, Sun, \& } \\
\text { Xu (2015) }\end{array}$ & AT & $\begin{array}{l}\text { World Bank } 120 \text { city survey of } 12,400 \\
\text { Chinese manufacturing firms conducted in } \\
2005 \text {. }\end{array}$ & $\begin{array}{l}\text { Government connections associated with substantially less severe } \\
\text { financial constraints. }\end{array}$ & China \\
\hline 4. & $\begin{array}{l}\text { Liang, Ren, \& } \\
\text { Sun }(2015)\end{array}$ & AT, IT, IP & $\begin{array}{l}\text { 2,394 listed non-financial Chinese firms, } \\
80 \% \text { market capitalization of which are } \\
\text { SOEs, 2001-2011, Datastream, WIND, } \\
\text { CSMAR, and CCER }\end{array}$ & $\begin{array}{l}\text { Diminishing effect of executive political connections and } \\
\text { increasing effect of state ownership control on globalization } \\
\text { decisions and degree of globalization of SOEs with full or partial } \\
\text { state ownership. }\end{array}$ & China \\
\hline 5. & $\begin{array}{l}\text { Lin, Tan, Zhao \& } \\
\text { Karim }(2015)\end{array}$ & AT & $\begin{array}{l}\text { All firms with listed A-shares on Shenzhen } \\
\text { or Shanghai stock exchange 2005-2009. } \\
\text { Publicly available data. }\end{array}$ & $\begin{array}{l}\text { Firms spending resources to bond with new government via CSR } \\
\text { activities receive higher levels of government subsidies or have } \\
\text { greater propensity to receive future government subsidies. They } \\
\text { outperform firms not investing in political networking via CSR. }\end{array}$ & China \\
\hline 6. & $\begin{array}{l}\text { Qian \& Yeung } \\
(2015)\end{array}$ & AT & $\begin{array}{l}\text { All Chinese listed firms } 1995-2009 . \\
\text { Chinese Security Market Research } \\
\text { (CSMAR) database. }\end{array}$ & $\begin{array}{l}\text { Controlling shareholders' tunneling activity positively associated } \\
\text { with firms' state owned bank loan access. }\end{array}$ & China \\
\hline 7. & $\begin{array}{l}\mathrm{Li}, \mathrm{Cui}, \& \mathrm{Lu} \\
(2014)\end{array}$ & IT, IP & $\begin{array}{l}16 \text { illustrative case examples from South } \\
\text { East Asia and China }\end{array}$ & $\begin{array}{l}\text { Restructuring of central SOEs into "national champions" exposes } \\
\text { them to stronger institutional pressures from home and host } \\
\text { country governments; local SOEs with fewer obligations to serve } \\
\text { national strategic prerogatives display greater managerial } \\
\text { autonomy and market orientation. }\end{array}$ & $\begin{array}{l}\text { South East } \\
\text { Asia and } \\
\text { China }\end{array}$ \\
\hline 8. & Meyer, Ding, Li, & IT & 386 foreign investments of listed Chinese & SOEs face more complex institutional pressures in host countries & China \\
\hline
\end{tabular}




\begin{tabular}{|c|c|c|c|c|c|}
\hline & \& Zhang (2014) & & firms 2009 , public data. & $\begin{array}{l}\text { than private firms, adapting mode and control decisions } \\
\text { differently. }\end{array}$ & \\
\hline 10. & $\begin{array}{l}\text { Zeng, Douglas } \\
\text { and } \mathrm{Wu}(2013)\end{array}$ & IT, RBV & $\begin{array}{l}\text { Chinese beer industry, } 1995-2004 \text { ( } 661 \\
\text { firms } 1995 \text { and } 231 \text { in } 2004 \text {, and } 93 \\
\text { acquisitions). } 70 \% \text { founded as SOEs; } \\
\text { CNBS. }\end{array}$ & $\begin{array}{l}\text { Firms founded as SOEs or COEs (Collectively Owned } \\
\text { Enterprises) desire acquisition, unless have undertaken multiple } \\
\text { changes, or attracted more private investment. Acquisition } \\
\text { likelihood has U-shaped relationship with investment in } \\
\text { marketing resources. }\end{array}$ & China \\
\hline 11. & Chernykh (2011) & AT & 153 privately-controlled firms, 2003. & $\begin{array}{l}\text { Formerly privatized and domestically-owned companies in } \\
\text { strategically important sectors face highest risks of transfers from } \\
\text { private to state control. Renationalization not driven by firm } \\
\text { profitability. }\end{array}$ & Russia \\
\hline 12. & $\begin{array}{l}\text { Wang, Guthrie, \& } \\
\text { Xiao (2011). }\end{array}$ & IT & Chinese listed firms, 1994-2003. & $\begin{array}{l}\text { Analysis of how SASAC impacts ownership concentration and } \\
\text { allows firm owners to monitor and stabilize firm behavior. }\end{array}$ & China \\
\hline 13. & $\begin{array}{l}\text { Okhmatovskiy } \\
(2010)\end{array}$ & $\mathrm{PE}$ & $\begin{array}{l}450 \text { Russian banks } 2001,640 \text { banks } 2002 \text {, } \\
\text { and } 555 \text { banks } 2003 \text {, Central Bank of } \\
\text { Russia, Interfax and financial statements. }\end{array}$ & $\begin{array}{l}\text { Banks demonstrate higher profitability when they have ties to } \\
\text { SOEs but not when they have direct ties to state agencies. }\end{array}$ & Russia \\
\hline 15. & Chernykh (2008) & AT & Russian listed firms. & $\begin{array}{l}\text { Federal and regional governments' control is exercised through } \\
\text { elaborate pyramid structures. }\end{array}$ & Russia \\
\hline 16. & $\begin{array}{l}\text { Fan, Wong \& } \\
\text { Zhang (2007) }\end{array}$ & AT & $\begin{array}{l}790 \text { newly partially privatized firms in } \\
\text { China, covering } 7,255 \text { CEOs and directors, } \\
\text { 1993-2001. IPO prospectuses and other } \\
\text { public sources. }\end{array}$ & $\begin{array}{l}\text { Firms with politically connected CEOs underperform those } \\
\text { without and have poorer growth. Firms led by politically } \\
\text { connected CEOs more likely to appoint other bureaucrats to the } \\
\text { board rather than directors with relevant professional } \\
\text { backgrounds. }\end{array}$ & China \\
\hline 17. & $\begin{array}{l}\text { Ralston, Terpstra- } \\
\text { Tong, Terpstra, } \\
\text { Wang, \& Egri } \\
(2006)\end{array}$ & $\begin{array}{l}\text { Competing } \\
\text { values of } \\
\text { organizational } \\
\text { culture }\end{array}$ & $\begin{array}{l}\text { Survey of } 435 \text { SOEs, private-owned } \\
\text { enterprises, and foreign-controlled } \\
\text { businesses in manufacturing, } 2001 \text { and } \\
2002 \text {. }\end{array}$ & $\begin{array}{l}\text { SOEs in China have transitioned from their pre-reform culture } \\
\text { into market-oriented one. }\end{array}$ & China \\
\hline 18. & Uhlenbruck, & RBV, & Theoretical models leading to normative & Privatized SOEs improve learning ability by actively searching & Central and \\
\hline
\end{tabular}




\begin{tabular}{|c|c|c|c|c|c|}
\hline & $\begin{array}{l}\text { Meyer \& Hitt } \\
(2003)\end{array}$ & $\begin{array}{l}\text { Organizational } \\
\text { learning }\end{array}$ & propositions & $\begin{array}{l}\text { for information in product and factor markets rather than relying } \\
\text { on information provided by established networks. They should } \\
\text { also adapt organizational structure to allow for more efficient } \\
\text { information processing by integrating resources to achieve } \\
\text { strategic fit. }\end{array}$ & $\begin{array}{l}\text { Eastern } \\
\text { Europe }\end{array}$ \\
\hline 20. & $\begin{array}{l}\text { Ferguson, Lam \& } \\
\text { Lee (2002) }\end{array}$ & $\begin{array}{l}\text { Cost-benefit } \\
\text { framework }\end{array}$ & $\begin{array}{l}145 \text { Hong Kong stock exchange firms, } \\
1995-96 .\end{array}$ & $\begin{array}{l}\text { Chinese formerly wholly owned SOEs cross-listed on Hong Kong } \\
\text { stock exchange disclose more information than other firms listed } \\
\text { in China. }\end{array}$ & China \\
\hline 21. & $\begin{array}{l}\text { Filatotchev, Buck } \\
\& \text { Zhukov }(2000)\end{array}$ & AT & $\begin{array}{l}\text { Medium and large industrial firms; } \\
\text { questionnaire interviews 1997/1998. }\end{array}$ & $\begin{array}{l}\text { Downsizing following privatization influenced by corporate } \\
\text { governance and institutional change caused by business crisis. }\end{array}$ & CIS \\
\hline 22. & White (2000) & $\begin{array}{l}\text { TCE, RBV, and } \\
\text { RDT }\end{array}$ & China's pharmaceutical SOEs 1985-94. & $\begin{array}{l}\text { SOEs' M\&A decisions are outcomes of a simultaneous } \\
\text { consideration of external competitive and internal capabilities- } \\
\text { related factors. }\end{array}$ & China \\
\hline 23. & $\begin{array}{l}\text { Cao, Qian \& } \\
\text { Weingast (1999) }\end{array}$ & IP & Business history narrative & $\begin{array}{l}\text { Privatization and reforms in China driven by the federal } \\
\text { government. }\end{array}$ & China \\
\hline
\end{tabular}

Review studies are not included. Abbreviations: AT - agency theory, TCE - transaction cost economics, IT - institutional theory, RBV - resource-based view, IP - industrial policy, PE - political embeddedness, RDT - resource dependence theory. 
TABLE 3

Events that Affected State Control and Corporate Governance in China during last 25 Years

\begin{tabular}{|c|c|c|c|}
\hline Year & Event & What has changed as the result of this event & Implications for state control and corporate governance \\
\hline $\begin{array}{l}1990- \\
1991\end{array}$ & $\begin{array}{l}\text { Shanghai stock exchange } \\
\text { opens in December 1990, } \\
\text { Shenzhen stock exchange } \\
\text { opens in July } 1991\end{array}$ & $\begin{array}{l}\text { Organized share trading makes it easy for companies to sell } \\
\text { shares and for investors to buy shares. Category of minority } \\
\text { shareholders dramatically expanded to include different types } \\
\text { of return-seeking investors. }\end{array}$ & $\begin{array}{l}\text { Principal reason for opening Shanghai and Shenzhen stock exchanges } \\
\text { was to provide an opportunity for SOEs to raise funds. By selling shares } \\
\text { to private investors the state diluted its holdings in SOEs. }\end{array}$ \\
\hline 1992 & CSRC established & $\begin{array}{l}\text { The China Securities Regulatory Commission (CSRC) an } \\
\text { analogue of U.S. SEC. The CSRC formulates and enforces } \\
\text { rules regulating how securities are issued and traded. }\end{array}$ & $\begin{array}{l}\text { CSRC gradually gained significant influence as an independent } \\
\text { regulatory agency that reports directly to the State Council. CSRC } \\
\text { regulations restrict state shareholders in how they exercise control. }\end{array}$ \\
\hline $\begin{array}{l}1993- \\
1994\end{array}$ & $\begin{array}{l}\text { Company Law passed in } \\
\text { December 1993, effective } \\
\text { since July } 1994\end{array}$ & $\begin{array}{l}\text { Company Law formulated general rules applying to all limited } \\
\text { liability companies and joint stock corporations. }\end{array}$ & $\begin{array}{l}\text { Once corporatized, SOEs fall under jurisdiction of the Company Law. } \\
\text { The state, as the main shareholder, is constrained by this Law in how it } \\
\text { exercises control over SOEs (and has to respect rights of private } \\
\text { minority shareholders). }\end{array}$ \\
\hline 2001 & Accession to WTO & $\begin{array}{l}\text { Substantial increase in foreign investments into sectors that } \\
\text { used to be closed for foreign ownership. }\end{array}$ & $\begin{array}{l}\text { SOEs become partners of foreign investors in newly-created joint } \\
\text { ventures, exposing SOEs to technologies and management practices of } \\
\text { foreign partners. }\end{array}$ \\
\hline 2002 & $\begin{array}{l}\text { Code of Corporate } \\
\text { Governance issued }\end{array}$ & $\begin{array}{l}\text { Code provides general non-mandatory guidelines addressing } \\
\text { most important aspects of corporate governance; companies } \\
\text { are expected to disclose information about non-compliance. }\end{array}$ & $\begin{array}{l}\text { Code requires that independent directors play an important role so that } \\
\text { they potentially may prevent unilateral control of the board by state } \\
\text { representatives. }\end{array}$ \\
\hline 2003 & $\begin{array}{l}\text { Removing restrictions on } \\
\text { ownership of A-shares by } \\
\text { domestic shareholders } \\
\text { only }\end{array}$ & $\begin{array}{l}\text { Qualified foreign institutional investors permitted to invest in } \\
\text { A-shares, expanding significantly the number of companies } \\
\text { that could be potential investment targets for foreign } \\
\text { institutional investors. }\end{array}$ & $\begin{array}{l}\text { Range of SOEs exposed to foreign institutional investors expands from } \\
107 \text { companies that issued B-shares to all traded companies. Number of } \\
\text { companies where state shareholders have to interact with foreign } \\
\text { shareholders increases dramatically. }\end{array}$ \\
\hline 2003 & SASAC established & $\begin{array}{l}\text { Companies previously owned directly by state agencies now } \\
\text { owned by State-Owned Assets Supervision and } \\
\text { Administration Commission (SASAC). SASAC oversees } \\
\text { SOEs on behalf of the State Council (Central Government). }\end{array}$ & $\begin{array}{l}\text { SASAC becomes intermediary between central government agencies } \\
\text { and SOEs thus decreasing politically-motivated interventions in } \\
\text { corporate governance of SOEs. }\end{array}$ \\
\hline 2005 & $\begin{array}{l}\text { Conversion of non- } \\
\text { tradable shares into } \\
\text { tradable shares }\end{array}$ & $\begin{array}{l}\text { Before } 2005 \text { companies would have two classes of shares: } \\
\text { tradable and non-tradable shares. Most shares were non- } \\
\text { tradable. }\end{array}$ & $\begin{array}{l}\text { Once non-tradable shares are converted into tradable shares, state } \\
\text { shareholders (and top executives appointed by state shareholders) } \\
\text { become interested in increasing share price as shares now potentially } \\
\text { can be sold for profit. }\end{array}$ \\
\hline $\begin{array}{l}2008- \\
2012\end{array}$ & $\begin{array}{l}\text { State support after the } \\
\text { global financial crisis } \\
\text { helped SOEs to gain } \\
\text { ground over private } \\
\text { companies }\end{array}$ & $\begin{array}{l}\text { As companies felt effects of } 2008 \text { worldwide financial crisis, } \\
\text { Chinese state focused on providing support to SOEs, while } \\
\text { refusing to provide similar support to private enterprises. }\end{array}$ & $\begin{array}{l}\text { SOEs expand operations at expense of private enterprises (the process } \\
\text { described as "guo jin min tui" or "the state advances, the private sector } \\
\text { retreats"). }\end{array}$ \\
\hline
\end{tabular}

Corporate Governance: An International Review 
TABLE 4

\section{Events that Affected State Control and Corporate Governance in Russia during Last 25 Years}

\begin{tabular}{|c|c|c|c|}
\hline Year & Event & What has changed as the result of this event & Implications for state control and corporate governance \\
\hline $\begin{array}{c}1987- \\
1988\end{array}$ & $\begin{array}{l}\text { USSR law on state } \\
\text { enterprises (effective 1988) }\end{array}$ & $\begin{array}{l}\text { Creating legal basis for operation of SOEs as relatively } \\
\text { autonomous economic actors. }\end{array}$ & $\begin{array}{l}\text { State retains full control over SOEs, but managers of SOEs granted } \\
\text { more autonomy. With launch of perestroika SOE managers are } \\
\text { encouraged to take initiative and assume responsibility for enterprise } \\
\text { performance. }\end{array}$ \\
\hline $\begin{array}{l}1990- \\
1991\end{array}$ & $\begin{array}{l}\text { Laws on ownership, } \\
\text { enterprises, and banking } \\
\text { (1990); law on privatization } \\
\text { (1991) enacted }\end{array}$ & $\begin{array}{l}\text { Creating legal basis for operation of enterprises with } \\
\text { different forms of ownership, including private } \\
\text { ownership and state ownership. Creating legal basis for } \\
\text { privatization. }\end{array}$ & SOEs for the first time face competition from privately-owned firms. \\
\hline $\begin{array}{l}1992- \\
1994\end{array}$ & Mass privatization & $\begin{array}{l}\text { Voucher privatization begins } 1992 \text {. Monetary } \\
\text { privatization begins } 1994 .\end{array}$ & $\begin{array}{l}\text { State releases control over SOEs in sectors not considered strategic. } \\
\text { Some completely privatized, others - partially privatized. }\end{array}$ \\
\hline 1995 & $\begin{array}{l}\text { Loans-for-shares } \\
\text { privatization begins }\end{array}$ & $\begin{array}{l}\text { Privatization of large enterprises in most attractive } \\
\text { sectors of the Russian economy through "loans-for- } \\
\text { shares" auctions. }\end{array}$ & $\begin{array}{l}\text { State releases control over some "jewels" of the national economy, } \\
\text { most engaged in extraction of natural resources and generating } \\
\text { significant revenues from export. }\end{array}$ \\
\hline 1996 & $\begin{array}{l}\text { Law on Corporations and } \\
\text { Law on Securities are } \\
\text { enacted }\end{array}$ & Creating legal basis for operation of stock markets. & $\begin{array}{l}\text { Large partially-privatized SOEs become blue chips of Russian stock } \\
\text { market while state retained majority stakes. }\end{array}$ \\
\hline 1998 & $\begin{array}{l}\text { Financial crisis, default on } \\
\text { government debt }\end{array}$ & $\begin{array}{l}\text { Government default and devaluation of ruble led to sharp } \\
\text { decline in imports and prompted development of local } \\
\text { producers. }\end{array}$ & $\begin{array}{l}\text { Many SOEs on verge of bankruptcy since mid-1990s benefited from } \\
\text { increasing demand for local products after } 1998 \text { crisis - became viable, } \\
\text { made investments, but needed to improve efficiency. }\end{array}$ \\
\hline 2000 & $\begin{array}{l}\text { Putin's first term as } \\
\text { President begins }\end{array}$ & $\begin{array}{l}\text { Under Putin, trend of "state capture" by oligarchs } \\
\text { reversed; soon after Putin's election several influential } \\
\text { oligarchs fled Russia, others expressed willingness to } \\
\text { cooperate. }\end{array}$ & $\begin{array}{l}\text { State begins to reassert control over economy largely lost under Yeltsin. } \\
\text { State shareholders remained passive in the 1990s but after } 2000 \text { state } \\
\text { began to leverage its rights as a major shareholder and assumed a more } \\
\text { active role in corporate governance. }\end{array}$ \\
\hline 2002 & $\begin{array}{l}\text { Corporate Governance Code } \\
\text { enacted }\end{array}$ & $\begin{array}{l}\text { Russian Corporate Governance Code provided detailed } \\
\text { guidelines, officially endorsed by the government. Not } \\
\text { mandatory, but publicly traded companies required to } \\
\text { report and explain non-compliance. }\end{array}$ & $\begin{array}{l}\text { Code of Corporate Governance formulates standards of good corporate } \\
\text { governance targeting primarily publicly traded companies including } \\
\text { companies with partial state ownership. Recommends mechanisms } \\
\text { preventing controlling shareholders from taking actions harming } \\
\text { interests of minority shareholders. Such policies constrain control by } \\
\text { state as majority shareholder. }\end{array}$ \\
\hline 2003 & $\begin{array}{l}\text { Arrest of Yukos's largest } \\
\text { shareholder Khodorkovsky, }\end{array}$ & $\begin{array}{l}\text { Arrest of Khodorkovsky, the wealthiest Russian in } 2003 \text {, } \\
\text { demonstrated toughness of Putin's administration toward }\end{array}$ & $\begin{array}{l}\text { Assets of Yukos purchased by state-controlled Rosneft. Expansion of } \\
\text { state-controlled companies through purchasing assets from private }\end{array}$ \\
\hline
\end{tabular}




\begin{tabular}{|c|c|c|c|}
\hline & $\begin{array}{l}\text { re-nationalization of Yukos } \\
\text { begins }\end{array}$ & $\begin{array}{l}\text { non-loyal oligarchs, after which no other oligarchs } \\
\text { explicitly opposed Putin's policies. }\end{array}$ & $\begin{array}{l}\text { companies continued, with proportion of total market capitalization } \\
\text { accounted for by SOEs increasing from } 20 \% \text { in } 2003 \text { to } 50 \% \text { in } 2010 \text {. }\end{array}$ \\
\hline 2011 & $\begin{array}{l}\text { Removing high-ranked } \\
\text { government officials from } \\
\text { boards of SOEs }\end{array}$ & $\begin{array}{l}\text { Replacing significant proportion of state representatives } \\
\text { on boards with independent directors and attorneys } \\
\text { voting according to government directives. }\end{array}$ & $\begin{array}{l}\text { Initiative intended to demonstrate de-politicization of governance of } \\
\text { SOEs. In practice did not increase autonomy of SOEs because lower } \\
\text { ranked government officials retained director positions and voted } \\
\text { according to directives received from top level officials. }\end{array}$ \\
\hline 2012 & Russia joins WTO & $\begin{array}{l}\text { Liberalization of trade: } 500 \text { legal measures adopted, } \\
\text { amended or modified to bring legal regime into } \\
\text { conformity with the WTO rules. Russia agreed that } \\
\text { SOEs participate in international trade in a manner } \\
\text { consistent with the WTO regulations. Russia took steps } \\
\text { to eliminate special privileges for many SOEs. }\end{array}$ & $\begin{array}{l}\text { WTO challenges some government policies and actions involving } \\
\text { SOEs. In 2015, US opposed new resolutions that would authorize } \\
\text { Russian government to frame procurement plans or tender rules to } \\
\text { effectively require SOEs to purchase Russian goods only as inconsistent } \\
\text { with Russia's WTO obligations. }\end{array}$ \\
\hline 2014 & $\begin{array}{l}\text { New version of Corporate } \\
\text { Governance Code introduced }\end{array}$ & $\begin{array}{l}\text { The revised version of the Code contains stricter } \\
\text { corporate governance requirements compared with the } \\
\text { original version. }\end{array}$ & $\begin{array}{l}\text { Top government officials, including Prime-Minister Medvedev, } \\
\text { emphasize that SOEs should make special efforts to comply with } \\
\text { requirements of the new Code. }\end{array}$ \\
\hline
\end{tabular}




\section{TABLE 5}

Transition Economies: Agenda for Further Research

\begin{tabular}{|c|c|}
\hline \multicolumn{2}{|r|}{ State Control } \\
\hline Theme & Research questions \\
\hline $\begin{array}{l}\text { State Control } \\
\text { through } \\
\text { Ownership }\end{array}$ & $\begin{array}{l}\text { What are the impacts of different forms of state ownership and affiliation on governance, strategy and performance? } \\
\text { How have different forms of state ownership and affiliation evolved? Is this evolution unidirectional away from state involvement? } \\
\text { How are the interests of private and public shareholders reconciled? } \\
\text { How do corporate governance bundles vary between different forms of state ownership and affiliation? } \\
\text { What are the forms of indirect state ownership and how do these impact governance and performance? } \\
\text { What new forms of state ownership and affiliation are emerging and how do their forms of control vary? } \\
\text { How does state ownership vary across geographic regions and administrative levels (i.e. federal vs. municipal)? }\end{array}$ \\
\hline $\begin{array}{l}\text { Means of State } \\
\text { Control beyond } \\
\text { Ownership }\end{array}$ & $\begin{array}{l}\text { How do channels of state non-equity control and support differ from each other and what is their impact? } \\
\text { What are the implications for private firms' ability to compete with state-supported firms and SOEs receiving financial and other resources from the } \\
\text { state? }\end{array}$ \\
\hline $\begin{array}{l}\text { Networks of } \\
\text { Private and State } \\
\text { Actors }\end{array}$ & $\begin{array}{l}\text { What is the nature of private-public governance mechanisms and networks and what is their impact? } \\
\text { How does the variety of private-public ownership forms relate to different approaches to private-public sector governance? } \\
\text { How does personal and organizational embeddedness in specific political networks influence governance? How does this change when executives and } \\
\text { board members change? }\end{array}$ \\
\hline $\begin{array}{l}\text { Evolution of State } \\
\text { Control }\end{array}$ & $\begin{array}{l}\text { How has state ownership and control of enterprises evolved in different types of transition economies and what has been the impact upon enterprises } \\
\text { in these economies? }\end{array}$ \\
\hline \multicolumn{2}{|r|}{ Corporate Governance } \\
\hline Theme & Research questions \\
\hline Boards & $\begin{array}{l}\text { To what extent do transition economy state-owned and controlled firms recruit overseas directors or expatriates who can provide the expertise } \\
\text { required? } \\
\text { How do the dimensions of board diversity (political/commercial, gender, age/experience, etc.) differ in firms with different configurations of state } \\
\text { control? } \\
\text { What board roles do politically connected directors play in different types of state-owned and affiliated enterprises? } \\
\text { What is the pattern of political and commercial expertise in Chair and CEO board roles? } \\
\text { To what extent does duality of Chair and CEO vary between different forms of state ownership and affiliation? } \\
\text { What is the nature of board turnover and its drivers in different types of state ownership and affiliation? } \\
\text { To what extent does social capital of state directors evolve (for example, decline or metamorphose) with the progress of market reforms? } \\
\text { How does the nature of board processes in firms with different configurations of state control vary? }\end{array}$ \\
\hline $\begin{array}{l}\text { Outsourcing of } \\
\text { Corporate } \\
\text { Governance } \\
\text { Regulation }\end{array}$ & $\begin{array}{l}\text { How does the selection of market tier at foreign stock exchanges impact SOE's corporate governance and performance? How does the country in } \\
\text { which the stock exchange is located affect implications of the foreign listing? } \\
\text { How do different formal stock exchange rules and informal enforcement mechanisms impact corporate governance and performance of SOEs listed at } \\
\text { foreign stock exchanges? }\end{array}$ \\
\hline
\end{tabular}




\begin{tabular}{|c|c|}
\hline $\begin{array}{l}\text { Transparency and } \\
\text { Disclosure }\end{array}$ & $\begin{array}{l}\text { What are the similarities and differences in transparency and disclosure practices between different transition economies and developed economies? } \\
\text { What drives these differences? } \\
\text { How does the enforcement and application of transparency and disclosure practices vary between different transition economies? } \\
\text { How does the enforcement and application of transparency and disclosure practices vary between different types of state ownership / affiliation and } \\
\text { private sector enterprises? }\end{array}$ \\
\hline $\begin{array}{l}\text { Executive } \\
\text { Compensation }\end{array}$ & $\begin{array}{l}\text { How does executive compensation in state-owned / affiliated enterprises in transition economies differ from executive compensation in non-state } \\
\text { firms and in enterprises from non-transition economies? } \\
\text { How does the status of state-owned / affiliated enterprises in transition economies affect the scope of executive compensation mechanisms available? }\end{array}$ \\
\hline $\begin{array}{l}\text { Evolution of } \\
\text { Governance } \\
\text { Mechanisms }\end{array}$ & $\begin{array}{l}\text { How have governance mechanisms and processes evolved in state-owned / affiliated enterprises in different types of transition economies and what } \\
\text { has been the impact upon enterprises in these economies? } \\
\text { To what extent do the presence and roles of politically connected directors in state-owned / affiliated enterprises change as transition economies } \\
\text { evolve? }\end{array}$ \\
\hline
\end{tabular}

